\title{
Simulation of Photovoltaic Water Pumping System for Small Scale Irrigation and Rural Electrification by Using PVsyst: Case of Madhicho, W/Harerghe, Oromia, Ethiopia
}

\author{
Mohammed Aliyi", Nade Nuru \\ Institute of Technology, Oda Bultum University, Chiro, Ethiopia \\ Email address: \\ mohammedaliyi610@gmail.com (M. Aliyi) \\ ${ }^{*}$ Corresponding author
}

To cite this article:

Mohammed Aliyi, Nade Nuru. Simulation of Photovoltaic Water Pumping System for Small Scale Irrigation and Rural Electrification by Using PVsyst: Case of Madhicho, W/Harerghe, Oromia, Ethiopia. International Journal of Energy and Power Engineering. Vol. 9, No. 4, 2020, pp. 49-68. doi: 10.11648/j.ijepe.20200904.12

Received: August 26, 2020; Accepted: September 21, 2020; Published: October 12, 2020

\begin{abstract}
Energy is one of the key factors for development of the country, and it can gain from different sources, but some of these sources are not environmentally friend, expensive and difficult to transport; like fossil fuel. Using solar energy is the best option to solve this problem. The objective of this study is Simulation of Photovoltaic water pumping system for small scale irrigation and rural electrification by using PVsyst soft-wares. The people living in grid connected system use electric powered pumping or diesel generator for pumping water, but people living in rural off-grid area can't get electric powered pump. Therefore this problem would be solved when they use solar photovoltaic pumping. In this work Madhicho is study area of this study is done at $9.14^{\circ}$ latitude and $40.75^{\circ}$ longitude. In this study analysis of PV water pump by using PVsyst or RET Screen Expert. Most of the time the major problem of solar PV water pumping system technology has been the wastage of energy in idle manner without using energy which is only used for target of specific purpose and time but in this research when no need of irrigation, the systems require batteries to store the sun's energy for use during summer periods. Total quantity of water required for irrigation is 145125liter per day the Pump power that can able to pump water from well to storage tank is $20 \mathrm{kw}$ the number of PV module to satisfy pump power is 55 and total energy produced from solar panel $22 \mathrm{kw}$. Solar PV water pumping system can be reliably used at where absence of continuous local grid available where as solar PV and battery storage need is critical
\end{abstract}

Keywords: Solar PV System, Water Pumping System, PVsyst, Battery

\section{Introduction}

Energy is the ability to do work and essential to mankind as he makes use of it in his daily life. It is one of the indispensable factors for continuous development and economic growth. The demand of energy is increasing rapidly in the developing countries due to automation, industrialization and urbanization. The growing population and technological developments have shown that the present sources of energy in use are not adequate. Some energy sources are not environmentally friendly, expensive and difficult to transport; like fossil fuel. Some energy sources are friendly with environment like wind energy, solar energy. Ethiopia has huge potential for solar energy because it is located near the equator with an average daily solar radiation of $5.25 \mathrm{kWh} / \mathrm{m}^{2}$ [1] Many researches done on Photovoltaic using for water pumping which used for drink, irrigation, livestock, wash and etc. [2] proposed a 'switched-mode' PVpowered pumping system. But in Ethiopia water pumping requirement for irrigation is not constant in all season. As Ethiopia water pumping requirement for irrigation is start from November up to April and exchanging product also has high value in this season.

The objective of this study is using solar energy for other purpose during no need water pumping requirement in summer (kiremt) season by using battery storage of $\mathrm{pv}$ for multi-purpose such as milling, refrigerator, television.

The Ethiopian rural area demand water for crop irrigation 
and domestic water supplies is increasing due to weather change that has going in the country. Agricultural technology is changing rapidly. Farm machinery, farm building and production facilities are constantly being improved. Solar Photovoltaic water pumping system is one of the best technologies that utilize the solar energy to pump water from deep well underground water sources and to solve electricity problem in rural area. The power from solar PV can drive both AC and DC motors to power a mill, and with technological advancement and falling prices of $\mathrm{PV}$ technology, solar milling has become increasingly economically viable. Among the economic benefits of introducing a solar mill is the potential for savings on spending on alternative fuels, in cases where it replaces a diesel-powered mill. For example, 1,200 litres of diesel could be saved per year in Ethiopia through one solar mill. a solar mill was installed in a village in Senegal with power requirement of less than 100 Watts (W) [3].
Ethiopia has favorable solar energy resources to use for off-grid photo voltaic systems for rural population. The higher price of diesel increases operation costs of diesel water pumping system thereby, reducing the incomes [4]. Off-grid solar photovoltaic (PV) system is an obvious choice for bringing modern energy supply to the remote Ethiopian communities existing power line [5]. Studied the potential of solar water pumping in Jordan and selected 10 sites based on the availability of solar radiation data under three categories: adequate, promising and poor and suggested other water pumping alternatives for these sites.

When properly sized and installed, PV water pumps are very reliable and require little maintenance. Agricultural applications suitable for photovoltaic solutions are numerous. Water pumping is one of the simplest and most appropriate uses for photovoltaic. From crop irrigation to stock watering to domestic uses, photovoltaic powered pumping systems meet a broad range of water needs.

\section{Materials and Methods}

\subsection{Study Area}

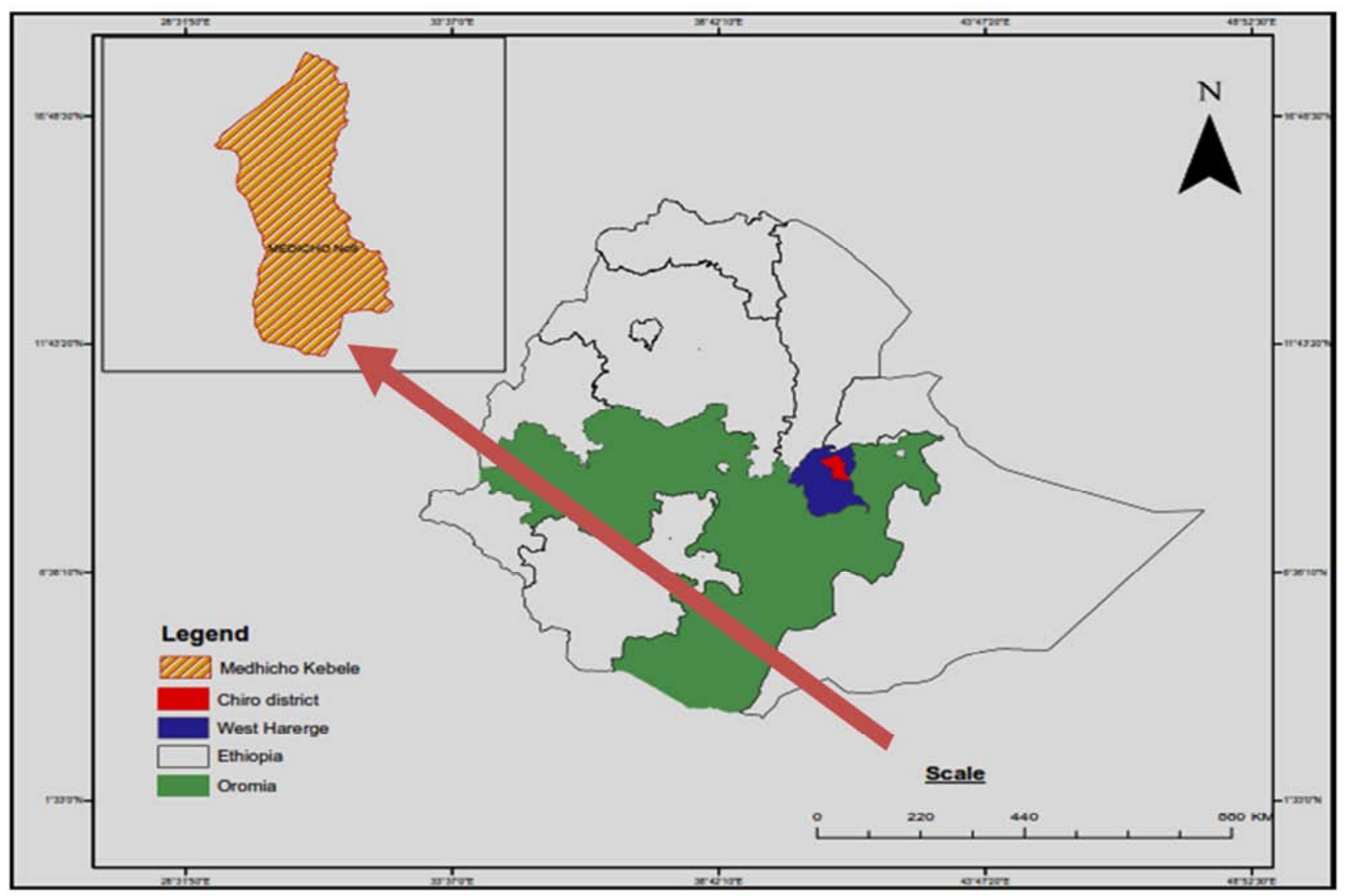

Figure 1. Location map of the study area.

The study area is located in West Harerghe Zone at Medhicho kebele which located 20kilometre from zonal capital town Chiro and 317 kilometres from regional and national capital city (Addis Ababa). The geographical location of this study area has latitude $9.14^{\circ} \mathrm{N}$ and longitude of $40.867^{\circ} \mathrm{E}$ and altitude of $1332 \mathrm{~m}$ above sea level.

\subsection{Data Type}

Data was collected secondary level through personal observation, structured interview, and design document and 
reviewing of archived data.

\subsection{Data Collection Process}

To achieve the objective of the study Secondary data was conducted on existing scenario and which have already been collected by someone else and which have already been passed through the statistical process.

1) Analysis of PV water pumping system which is a task that involves gathering of relevant information from a variety of sources.

2) Journals, reports, and internet.

\subsection{Data Processing and Analysis}

PVsyst software or RETScreen Expert was used to simulate the solar photovoltaic water pumping system for small scale irrigation before using software first identified inputs parameter, independent and dependent variable.

Following methodology can be adopted for present feasibility study

One method to analysis is to identified independent variable such as pump selection, size of photovoltaic module, land available and water required on command area, discharge from well and total head etc dependent variable like output parameters which are obtained from software such as energy at operating pump, array output energy, water needs to user and water pumped. From the source by inputting Weather data of selected site to software energy required was determined that can be used for irrigation (bega season) and energy required for other purpose during no need of irrigation (keremt season).

During simulation analysis using PVsyst software the following points should be considered. The initial point is determining the global effective irradiation and the maximum power point (MPP), once irradiation and MPP determined, the simulation is dependent on the Pumping Type and Configuration [6]

Input parameter in to RETScreen expert like average temperature, relative humidity, precipitation showed that the effect of those weather data on monthly solar radiation

\subsection{Climatic Data}

After compare collected Recorded data and NASA, then we take a minimum solar radiation of nearby area of a site the reason if it applicable for the minimum value as well as it might be possible for maximum solar radiation. The climatic data location is Mi'eso which is near by the specific site of my study area of Madhicho. Madhicho is found between Chiro and Mi'eso the data was taken from Mi'eso station because no recorded weather data at Chiro station.

\subsection{Analysis of Photovoltaic Energy for the Selected Site}

The solar radiation is very important in calculating the amount of electricity generated by PV modules. The long term statistical data of solar sunshine hour is also very important in deriving an equation to calculate the solar radiation, and use in the design of the PV energy generation system. However, the solar radiation could be generated by the mathematical model which is developed based on the meteorological sunshine hour data.

The analysis follows from extra-terrestrial solar radiation calculation, monthly average terrestrial solar radiation determination up to daily solar radiation on the plane of solar module for the site.

\subsection{Solar Resource and Photovoltaic System}

The main electrical generator of the proposed system is photovoltaic panel which converts solar irradiation directly into Electricity. However, several factors need to be considered for an optimal PV system design to achieve the desired reliability of the system in a given environment. Since the solar radiation varies daily, hourly and seasonally the electricity produced by the PV array vary accordingly. Since the selected site has been very good solar irradiation throughout the year and battery storage is incorporated in the system to handle.

\section{Results and Discussion}

\subsection{System Analysis}

\subsubsection{Solar Radiation Data Collection and Solar Resource Assessment of Selected Site}

\section{i. Recorded Data at Mi'eso Station}

Data of selected site solar radiation is collected from recorded data at Mi'eso station.

Table 1. Average Monthly Solar radiation recorded data at station $\mathrm{MJ} / \mathrm{m}^{2} /$ day from 2003-2012.

\begin{tabular}{lllllllllllll}
\hline Lat. 9. 23 Long. 40.75 & Jan & Feb & Mar & Apr & May & Jun & Jul & Aug & Sep & Oct & Nov & Dec \\
\hline 10-year average & 20.30 & 21.05 & 21.28 & 20.28 & 21.56 & 19.76 & 18.99 & 19.53 & 19.16 & 20.64 & 20.90 & 18.89 \\
\hline
\end{tabular}

Source: from the existing data prepared by MOA in1990. (Miesoo metrology station \&LocClim climate estimator)

\section{ii. Collected Site Data from NASA}

Latitude 9.23 / Longitude 40.75 was chosen

Table 2. Average Monthly Insolation Incident on a Horizontal Surface (MJ/m²/day)(2003-2012).

\begin{tabular}{|c|c|c|c|c|c|c|c|c|c|c|c|c|}
\hline Lat. 9. 23 Long. 40.75 & Jan & Feb & Mar & Apr & May & Jun & Jul & Aug & Sep & Oct & Nov & Dec \\
\hline 10-year average & 20.21 & 20.91 & 21.26 & 20.36 & 21.38 & 19.71 & 19.03 & 19.61 & 18.06 & 20.58 & 20.83 & 18.75 \\
\hline
\end{tabular}

(Source NASA website data at http://eosweb.larc.nasa.gov 


\subsubsection{Method of Solar Energy Determination on the Plane of PV Panel}

The solar radiation is very important in calculating the amount of electricity generated by PV modules. The long term statistical data of solar sunshine hour is also very significant in deriving an equation to calculate the solar radiation, and to know amount of energy generate by solar array. Photovoltaic (PV) technology is used for generating electricity from the incoming solar radiation. Several attempts have been made to evaluate, monitor and improve the performance of different components of a PV system: a PV module [7-10]; $a$ battery [11]; a pump. These, and similar studies have been effective for improving the efficiency of the PV system components. However, several factors need to be considered for an optimal PV system design to achieve the desired reliability of the system in a given environment. However, the solar radiation could be generated by the mathematical model which is developed based on the meteorological sunshine hour data. The analysis follows from extra-terrestrial solar radiation calculation, monthly average terrestrial solar radiation determination up to daily solar radiation on the plane of solar module for the site. The algorithm used to calculate the radiation on the plane of the solar array would be shown as follows:

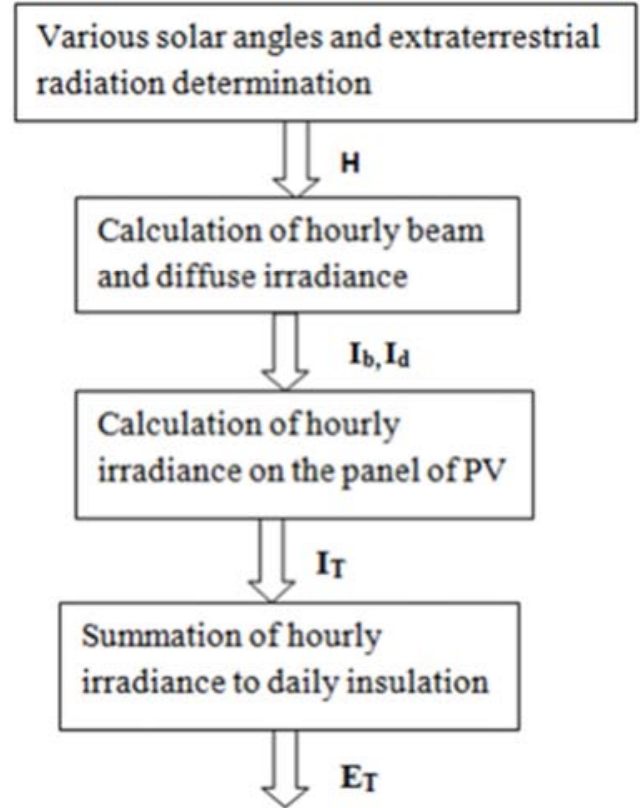

Figure 2 Flow Showing the Determination of Solar Energy on the Plane of PV Panel.

\subsubsection{Sizing of Solar PV System}

Sizing of photovoltaic system is based on the worst operating condition. For the purpose of the solar PV system design, solar data is available but check by numerically analysis in this method use the minimum monthly solar irradiation. In all, the solar-powered pumping system and the rainwater capture in the oil palm plantation can effectively meet the water need of the oil palm trees in the case study plantation [12].
Since, December month is minimum solar irradiation as shown in table 2. $\mathrm{N}=344$ is chosen for PV sizing, and the declination angle can be calculated using equation (1).

$$
z \delta=23.45 \sin \left[\frac{360}{365}(284+N)\right]
$$

Where $\mathrm{N}$ is day of year

$$
\delta=23.45 \cdot \sin [360 / 365(248+344)]=-23^{\circ}
$$

Hour angle $\omega$ and solar time ST in hour is related as equation (2).

Assuming 1:15PM for the selected site:

$$
\omega=(\mathrm{ST}-12)^{*} 15^{\circ}=13.15-12 * 15=17.25^{\circ}
$$

For horizontal surface, zenith $(\theta z)$ can be calculated using equation (3)

$$
\operatorname{Cos} \varphi \times \cos \delta \times \cos \omega+\sin \varphi \times \text { Sind }=\cos z
$$

$\cos \theta z=\cos 9.14 \times \cos -23 \times \cos \quad 17.25+\sin -23 \quad \times \sin$ $9.14=36.11^{\circ}$

Where, the latitude $\phi$ of the site is $9.14^{\circ}$

$$
\Theta z=36.11^{\circ}
$$

The relationship for the angle of incidence of surfaces sloped due north or due south can be derived from the fact that surfaces with slope $\beta$ to the north or south have the same angular relationship to beam radiation as a horizontal surface at an artificial latitude of $(\phi-\beta)$.

Slope $\beta$ for all year $\beta=\phi$ for summer $\beta=\phi-\left(10^{\circ}-15^{\circ}\right)$ and for

$$
\text { winter } \beta=\phi+\left(10^{\circ}-15^{\circ}\right)
$$

$$
\cos \theta=\cos \delta \times \cos \omega \times \cos (\phi-\beta)+\sin \delta \times \sin (\phi-\beta)
$$

Where: $\delta$ is the declination $\left({ }^{\circ}\right)$ calculated from (4.1) and $\phi$ is the site's latitude $\left(^{\circ}\right)$

$$
\begin{gathered}
\cos \theta=\cos (-23) \times \cos 17.25 \times \cos (9.14-9.14)+ \\
\sin (-23) \times \sin (9.14-9.14)=0.88 \\
\theta=28.4^{\circ}
\end{gathered}
$$

\section{i. Estimation of Solar Radiation}

The solar radiation passing through the atmosphere and reaching the earth's surface is classified into two components:

1) Beam radiation $I_{b}$ : is the solar radiation propagating along the line joining the receiving surface and the sun. It is also referred to as direct radiation.

2) Diffuse radiation $I_{d}$ : is the solar radiation scattered by aerosols, dust and molecules. It does not have a unique direction.

The total radiation I: is the sum of the beam and diffuse radiation and is sometimes referred to as the global radiation

ii. Estimation of Clear Sky Radiation on Horizontal Surface Achaibou et al [13] presented a simple model for the estimation of the transmittance of beam radiation in clear sky 
conditions. The inputs needed are the altitude of the location $\mathrm{A}$ in $\mathrm{km}$ above. Mean sea level, day number of the year $\mathrm{N}$ and the zenith angle $(\theta \mathrm{z})$. Combined with the Liu and Jordan's model for the transmittance of diffuse radiation through clear skies, the clear sky beam and diffuse radiation can be easily computed.

The clear sky beam radiation on a horizontal surface is:

$$
\mathrm{I}_{\mathrm{b}=} \mathrm{I}_{\mathrm{n}} \tau_{\mathrm{b}} \cos \theta_{\mathrm{z}}
$$

Where: $I_{n}=I_{s c}\left[1.0+0.033 \cos \left(\frac{360 \mathrm{~N}}{365}\right)\right]$

$=1367 \mathrm{w} / \mathrm{m}^{2}\left[1.0+0.033 \cos \left(\frac{360(344)}{365}\right)=1409 \mathrm{w} / \mathrm{m}^{2}\right.$

$$
\begin{array}{r}
\tau_{\mathrm{b}}=\mathrm{a}_{0}+\mathrm{a}_{1} \mathrm{e}^{\left(-\mathrm{k} / \cos \theta_{\mathrm{z}}\right)} \\
\mathrm{a}_{\mathrm{o}}=\mathrm{a}_{\mathrm{o}}^{*} \mathrm{r}_{\mathrm{o}}, \mathrm{a}_{1}=\mathrm{a}_{1}^{*} \mathrm{r}_{1}, \mathrm{k}=\mathrm{k}^{*} \mathrm{r}_{\mathrm{k}}
\end{array}
$$

Where,

$$
\begin{gathered}
\mathrm{a}_{\mathrm{o}}^{*}=0.4237-0.00821(6-\mathrm{A})^{2} \\
\mathrm{a}_{1}^{*}=0.5055+0.00595(6.5-\mathrm{A})^{2} \\
\mathrm{k}^{*}=0.2711+0.01858(2.5-\mathrm{A})^{2} \\
\mathrm{r}_{\mathrm{o}}=0.95, \mathrm{r}_{1}=0.91, \mathrm{r}_{\mathrm{k}}=1.02, \mathrm{~A}=\text { altitude in } \\
(1.332 \mathrm{~km})=1332 \mathrm{~m}
\end{gathered}
$$

$\mathrm{A}$ is altitude of the location in $\mathrm{km}$ above mean sea level

$$
\begin{aligned}
& \mathrm{a}_{\mathrm{o}}^{*}=0.4237-0.00821(6-1.332)^{2}=0.2448 \\
& \mathrm{a}_{1}^{*}=0.5055+0.00595(6.5-1.332)^{2}=0.6644 \\
& \mathrm{k}^{*}=0.2711+0.01858(2.5-1.332)^{2}=0.296
\end{aligned}
$$

Therefore,

$$
\begin{gathered}
\mathrm{a}_{\mathrm{o}}=\mathrm{a}_{\mathrm{o}}^{*} \mathrm{r}_{\mathrm{o}}=0.2448 \times 0.95=0.2326 \\
\mathrm{a}_{1}=\mathrm{a}_{1}^{*} \mathrm{r}_{1}=0.6644 \times 0.91=0.605 \\
\mathrm{k}=\mathrm{k}^{*} \mathrm{r}_{\mathrm{k}}=0.296 \times 1.02=0.3019
\end{gathered}
$$

Substitute the values into equation 7 gives:

$$
\tau_{\mathrm{b}}=0.2326+0.605 \mathrm{e}^{\left(-0.3019 / \cos 36.110^{\circ}\right)}=0.70
$$

Then using equation 6 to calculate beam radiation

$$
\mathrm{I}_{\mathrm{b}}=1409 \mathrm{w} / \mathrm{m}^{2} \times 0.7 \times \cos 36.11^{0}=800.17 \mathrm{w} / \mathrm{m}^{2}
$$

The transmittance of diffuse radiation through clear skies can be estimated from the beam radiation transmittance based on the study of Liu and Jordan:

$$
\tau_{\mathrm{d}}=0.271-0.2939 \tau_{\mathrm{b}}=0.271-0.2939 \times 0.7=0.080
$$

The clear sky diffuse radiation is:

$$
\begin{gathered}
\mathrm{I}_{\mathrm{d}}=\mathrm{I}_{\mathrm{n}} \tau_{\mathrm{d}} \cos \theta_{\mathrm{z}} \\
I_{d}=1409 \times 0.080 \times \cos 36.11^{\circ}=91.30 \mathrm{w} / \mathrm{m}^{2}
\end{gathered}
$$

So, the total clear sky radiation on a horizontal surface can be estimated as:

$$
\begin{gathered}
\mathrm{I}_{\mathrm{T}}=\mathrm{I}_{\mathrm{b}}+\mathrm{I}_{\mathrm{d}} \\
I_{T}=738.77+91.30=892 \mathrm{w} / \mathrm{m}^{2}
\end{gathered}
$$

\section{iii. Estimation of Solar Radiation on Inclined Surface}

The following formula was given by [14], for evaluating the total radiation on a surface of arbitrary orientation from knowledge of beam and diffuses radiation on horizontal surface.

$$
\mathrm{I}_{\mathrm{T}}=\mathrm{I}_{\mathrm{b}} \mathrm{R}_{\mathrm{b}}+\mathrm{I}_{\mathrm{d}} \mathrm{R}_{\mathrm{d}}+\mathrm{rR}_{\mathrm{r}}\left(\mathrm{I}_{\mathrm{b}}+\mathrm{I}_{\mathrm{d}}\right)
$$

Where:

$\mathrm{r}=$ reflectivity of the ground $=0.2$.

$\mathrm{Rb}, \mathrm{Rd}$ and $\mathrm{Rr}$ are known as conversion factors for beam, diffuse and reflected components respectively.

The expressions for these are as follows:

$\mathrm{Rb}$ : is defined as the ratio of flux of beam radiation incident on an inclined surface to that on a horizontal surface. The flux of beam radiation incident on a horizontal surface (Ib) is given by: $R_{b}=\frac{\cos \theta}{\cos \theta_{z}}=\frac{\cos 28.4^{0}}{\cos 36.11^{0}}=1.08$

$\mathrm{Rd}$ : is the ratio of the flux of diffuse radiation falling on the tilted surface to that on the horizontal surface. This conversion factor depends on the distribution of diffuse radiation over the sky and on the portion of sky seen by the surface.

$$
\mathrm{R}_{\mathrm{d}}=\frac{1+\cos \beta}{2}=\frac{1+\cos 9.14^{\circ}}{2}=0.994
$$

Rr: The reflected component comes mainly from the ground and other surrounding objects.

$$
\mathrm{R}_{\mathrm{r}}=\left(\frac{1-\cos \beta}{2}\right)=\left(\frac{1-\cos 9.14^{\circ}}{2}\right)=6 \times 10^{-3}
$$

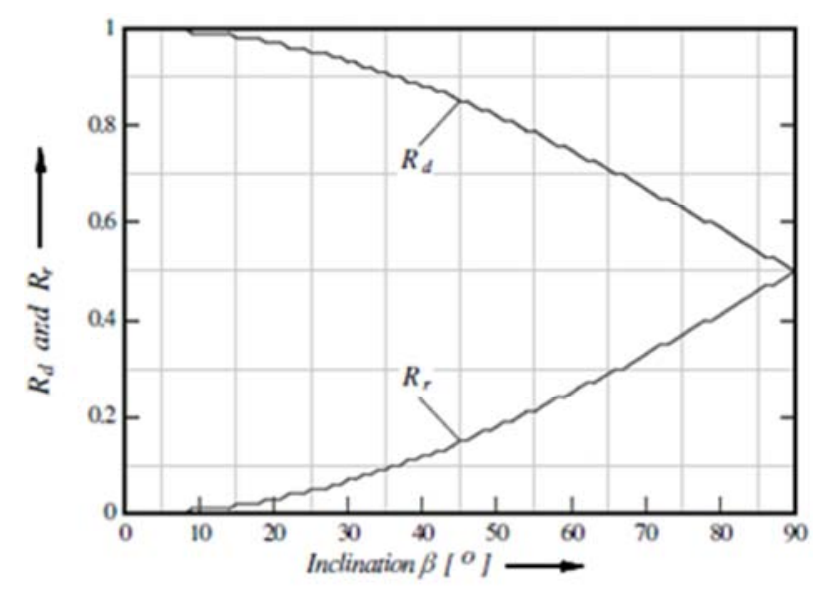

Figure 3. Variation of $R d$ and $R r$ with inclination.

In this case $\left(\beta=9.14^{\circ}\right), \mathrm{Rd}=0.994$ and $\mathrm{Rr}=6 \times 10^{-3}$

This indicates that small slop planes receive little reflected radiation and more deflection radiation.

Using equation 9 to determines solar radiation on inclined 
surface:

$$
\begin{gathered}
I_{T}=I_{b} R_{b}+I_{d} R_{d}+r R_{r}\left(I_{b}+I_{d}\right) \\
\mathrm{I}_{\mathrm{T}}=800 * 0.94+ \\
+91.30 \times 0.994+0.2 \\
\times 6 \times 10^{-3}(800+91.30) \\
\mathrm{I}_{\mathrm{T}}=844 \mathrm{~W} / \mathrm{m}^{2}
\end{gathered}
$$

December month is minimum solar radiation in selected site, but the calculated total solar radiation above that taken from data collection, therefore, the solar radiation of selected site enough for this system.

\section{iv. Peak Sun Hours}

For the purpose of the solar PV system design, the minimum monthly solar irradiation is used in determining the peak sun shine hours. This approach is usually required for the design of solar PV systems (designing for worst conditions).

Performance of solar PV system depends largely on the peak sun hours of the location of application. The peak sun hour(s) of an area is determined form the available solar irradiance of the location. The peak sun hours and total irradiation are related by Equation 11

After compare collected data of Recorded and NASA, then we take a minimum solar radiation of nearby area of a site. Now by definition Peak Sun hour is equivalent to calculated irradiance $844[\mathrm{w} / \mathrm{m} 2]$, the number of peak sun hours can be obtained by equation 11 using minimum monthly solar irradiation data in December $5.21 \mathrm{kWh} / \mathrm{m}^{2} /$ day from Table 2.

$$
\begin{gathered}
\mathrm{PSH}=\frac{\operatorname{Irrigation}\left[\mathrm{wh} / \mathrm{m}^{2} / \text { day }\right]}{\text { Peak } \operatorname{sun}\left[\mathrm{W} / \mathrm{m}^{2}\right]} \\
=5.21 * 1000 \mathrm{Wh} / \mathrm{m}^{2} / \text { day } / 831.061 \mathrm{w} / \mathrm{m}^{2}=6.27 \mathrm{~h} / \text { day }
\end{gathered}
$$

$\mathrm{PSH}=6.27 \mathrm{~h} /$ day (This peak sun hour is minimum value available in December)

Peak sun hour is the time period of pump can be operated daily its value is $6.27 \mathrm{~h} /$ day.

\subsubsection{System Sizing}

The electricity generation depends on the size of the PV cell, the conversion efficiency, and sunlight intensity of the local area [14].

\section{i. Determining of Solar PV Panel}

Now the main point that must be focused in this research is to find expected energy required from solar the PV panel which can able to satisfy pump power during winter season and another aspect during summer season due to different environmental factor like cloud wind temperature etc the amount of power output is become low at this time the PV panel power used for multipurpose (Appliance). The required power of the solar panel depends on the amount of energy demand to operate pumping. The Power requirement to operate Pump has power capacity around $27.5 \mathrm{kWpit}$ 's determined in section4.4.2 and power requirement for other purpose $132262 \mathrm{Wh}$ per day shown in table 7. It is used as supplementary power for other purpose has to be considered. The minimum solar radiation of site is $5.21 \mathrm{kwh} / \mathrm{m}^{2}$. The efficiency of maximum power point of module is $12.5-15 \%$ as shown in Table 3.

Array size

Daily horizontal solar radiation strike on tilted surface of Solar PV panel can provide energy demand. Array size can be obtained based on energy requirement and actual sunshine hour.

By considering system

Electrical power needed for pump power is $22 \mathrm{kw}$

Energy Requirement=Electrical power required* $6 \mathrm{hr}=1320,000 \mathrm{Wh} /$ day.

Now determine sizing of solar array

$$
\text { Array size (total wattage of PV panel) }=\frac{\text { Energy Requirement }}{\text { PSH }}(12)
$$

Assuming, actual sunshine hours or PSH peak sun hours $=6.27 \mathrm{~h} / \mathrm{d}$ and energy needed $=\frac{132,000 \mathrm{Wh} / \mathrm{d}}{6.27 \mathrm{~h} / \mathrm{d}}=22 \mathrm{~W}$

Total wattage of PV panel $=22000 \mathrm{~kW}=22 \mathrm{kw}$. Now calculate number of PV panel

$$
\begin{aligned}
& \mathrm{N} \underline{\mathrm{O}}_{\text {PV panel }}=\frac{\text { Capacity of plant }}{\text { PVmodule selected }} \\
& =22,000 \mathrm{WWp} / 400 \mathrm{Wp}=55
\end{aligned}
$$

But, the solar panels must also have additional capacity to account for any potential reduction in power due high heat, dust, age, etc. Many PV manufacturers recommend increasing the minimum peak power value by $25 \%$ to account for these environmental factors. Therefore, the PV panels can be sized to provide a minimum output of $22,000 \mathrm{Wp}^{*} 1.25=27,500 \mathrm{Watts}$ peaks. So that, the selected PV panel can produces above required power. Therefore the design is safe.

Therefore Number of solar PV panel to satisfy energy required is around $55 \mathrm{~W}$

Power loss

There are different loss presented during power PV power producing

wiring $\operatorname{loss}(1.5 \%)$ at STC

series $\operatorname{diod} \operatorname{loss}(0.1 \%)$ at STC

module quality loss $(1.5 \%)$

module mismatch losses (1.0\%) at MPP

total pv arry loss $=1.5+0.1+1.5+1=4.1 \%$

Solar PVpower $=25 * 0.959=23.97 \mathrm{kw}$

\section{ii. Module Selection}

Candidate Modules for the System

1. Generic: - model: $190 \mathrm{Wp} 54$ cells, nominal power 190.0 Wp technology: Si poly ISc 7.820A, Impp 7.250A, Voc $32.80 \mathrm{v}$, Vmpp $26.2 \mathrm{v}$, temperature coefficient $=0.05 \% /{ }^{\circ} \mathrm{C}$, module efficiency $12.92 \%$

2. BP Solar: -model: BP7180 S, nominal power $180 \mathrm{Wp}$, technologycrystalline silicon, ISc 5.3A, Impp 5A, Voc 44.2V, Vmp36V, temperature coefficient $0.05 \% /{ }^{\circ} \mathrm{C}$, module efficiency $14.3 \%$.

3. Mitsubishi: -model: PV-UD180mfs, nominal power: $180 \mathrm{Wp}$, technology: Si poly, ISc 8.03A, Impp 7.45A, Voc $30.4 \mathrm{~V}$, Vmpp24.2V, temperature coefficient $0.03 \% /{ }^{\circ} \mathrm{C}$, module efficiency $13.6 \%$.

4. Helios:-model:9T6 400Watt nominal power $400 \mathrm{Wp}$ technology: Mono-crystalline silicon,8.82A, Impp8.26A, 
Voc59.8V v, Vmpp 48.43v, temperature coefficient $=0.03 \% /{ }^{\circ} \mathrm{C}$, module efficiency $15 \%$

Candidate number four i.e. Helios Solar 9T6 400W technology module, is selected for this purpose because of its best efficiency and better temperature coefficient. It provides reliable photovoltaic power operating DC loads directly or, in an inverter-equipped system. With 400 watts of nominal maximum power, the 9T6 400 is used in utility-grid supplemental systems for residences, commercial buildings, and centralized power generation and in remote systems for applications including telecommunications, pumping and irrigation, remote villages and homes, and land-based aids to navigation.

Source: https://www.gogreensolar.com/pages/orangecounty-solar-company

Table 3. Electrical and mechanical characteristics of the selected PV module.

\begin{tabular}{ll}
\hline Electrical characteristics & Helios 9T6 400 \\
\hline Maximum power $\left(\mathrm{P}_{\max }\right)$ & $400 \mathrm{~W}$ \\
Power tolerances & $-3 \% /+5 \%$ \\
Number of cell & 96 \\
Voltage at $\mathrm{P}_{\max }\left(\mathrm{V}_{\mathrm{mp}}\right) \mathrm{k}$ & $48.43 \mathrm{~V}$ \\
Current at $\mathrm{P}_{\max }\left(\mathrm{I}_{\mathrm{mp}}\right)$ & $8.26 \mathrm{~A}$ \\
Open-circuit voltage $\left(\mathrm{V}_{\mathrm{oc}}\right)$ & $59.8 \mathrm{~V}$ \\
Short-circuit current $\left(\mathrm{I}_{\mathrm{sc}}\right)$ & $8.82 \mathrm{~A}$ \\
Temperature coefficient of $\mathrm{I}_{\mathrm{sc}}$ & $0.03 \% /{ }^{\circ} \mathrm{C}$ \\
Temperature coefficient of $\mathrm{V}_{\mathrm{oc}}$ & $-0.32 \mathrm{mV} /{ }^{\circ} \mathrm{C}$ \\
Temperature coefficient of power & $-0.41 \% /{ }^{\circ} \mathrm{C}$ \\
NOCT & $47 \pm 2{ }^{\circ} \mathrm{C}$ \\
Efficiency & $12.5-15 \%$ \\
Mechanical characteristics & \\
Type & Mono $(96 \mathrm{Cell})$ \\
Frame colour & $\mathrm{Clear}$ \\
Thickness & $40 \mathrm{~mm}$ \\
Width & $1,976 \mathrm{~mm}$ \\
Depth & $1,310 \mathrm{~mm}$ \\
Weight & $31.30 \mathrm{~kg}$ \\
Area: & $2.58 \mathrm{~m}{ }^{2}$ \\
$80 \%$ power output warranty period 25 years & \\
\hline
\end{tabular}

\subsubsection{Battery}

Batteries are one of the most sensitive equipment of a PV system and expensive too, accountings for nearly $20 \%$ to $40 \%$ of the total cost of the PV system for stand-alone applications. Battery is mostly used for purposes of solar power which during nights and cloudy days, we need to store the energy produced during the daytime, however in this research the purpose of using battery storage is that the time no need of irrigation and during low water demand from command area. The most commonly used batteries in the PV systems are the lead-acid and nickel cadmium batteries. But we use the Deep cycle battery, on account of its low cost and simple charging process.

\section{i. Summer Season Battery Storage}

The size of solar storage battery used in summer time required would be based on the appliance load energy demand the energy required of appliance such as florescent, mobile battery, TV, grain milling etc. And also depend on
Weather condition available at study area. When the storage battery to be installed its coupled with system in summer season irrigation is not required the reason to attach battery storage to the system is considered in order to solve scarcity of series problem of rural electricity faced people live nearby area, however in winter season due to water demand increase no need of battery storage the system can be coupled directly so battery storage should be removed from the system at this time battery become wait to sleep the most benefit to kept sleep battery at winter(bega) season is to increase the service life of battery. Having too much energy and storage capacity will increase cost, however, to design the solar PV water pumping system may need high initial cost but after a given period of time the system could be more advantage. The system mostly focused on irrigation time consequently temporary energy needed as supplementary power can supply to other purpose.

In the summer season Solar PV panels can be generate less energy at the study area, so the system may not generate enough solar electricity as winter to fully charge the battery during the summer months. Service lifetime of battery can be affected by long periods discharging battery. This is specifically the case for Deep cycle batteries so that to maintain battery health, the system may have a 'winter mode' setting that is during the winter by putting the battery to sleep to stop the discharge from it or charges it from the mains.

In this research battery only worked for appliance that critical in the rural community that can consume energy for small time therefore, this time a battery sleeping time is greater than discharging time.

Types of Selected Battery at Appendix-D: Battery Selection

The specification of the battery that we use is $1875 \mathrm{ah}$

1) Calculation for the number of batteries that we use in our project

2) Generally the sun gives $1000 \mathrm{~W} / \mathrm{m}^{2}$

A solar panel is $40 \%$ efficient so we get $400 \mathrm{~W}$ ( $40 \%$ of 1000)

Theoretically we use 55 panels each of 400 watts $(400 * 55=22,000 \mathrm{w})$ practically summer output power is 4049 $\mathrm{kW}$ from (tables 4-10)

The size of the appliance that we uses are $132262 \mathrm{Wh}$ per day) from (table 9)

$132262 * 30=3,967,860 \mathrm{w}-\mathrm{hr}=3,967.86 \mathrm{kwh} /$ month

132262 wh needed

Usually battery is specified in amp-hr

The specification of the battery that we use is $1875 \mathrm{Ah}$

We use $12 \mathrm{v}$ battery so132262 wh/12V=11,000A-h

1) No of Battery energy stored $=11000 / 1875 * .7=8$ assuming (Since battery is $70 \%$ efficient) battery loss is $30 \%$

2) We require 8 batteries to supply power

The useable storage capacity in kilo-watt hours $(\mathrm{kWh})$

Useable storage capacity $=\mathrm{A}$ $\mathrm{h} *$ voltage $=1875 \mathrm{ah} * 12 \mathrm{~V}=22.5 \mathrm{kwh}$. DOD) allowable depth of discharge, typically $80 \%$ for deep cycle batteries (lead acid battery) 
Stored energy $(80 \%)=0.80 * 22.5=19.125 \mathrm{kwh}$

Table 4. Module connections in parallel and series.

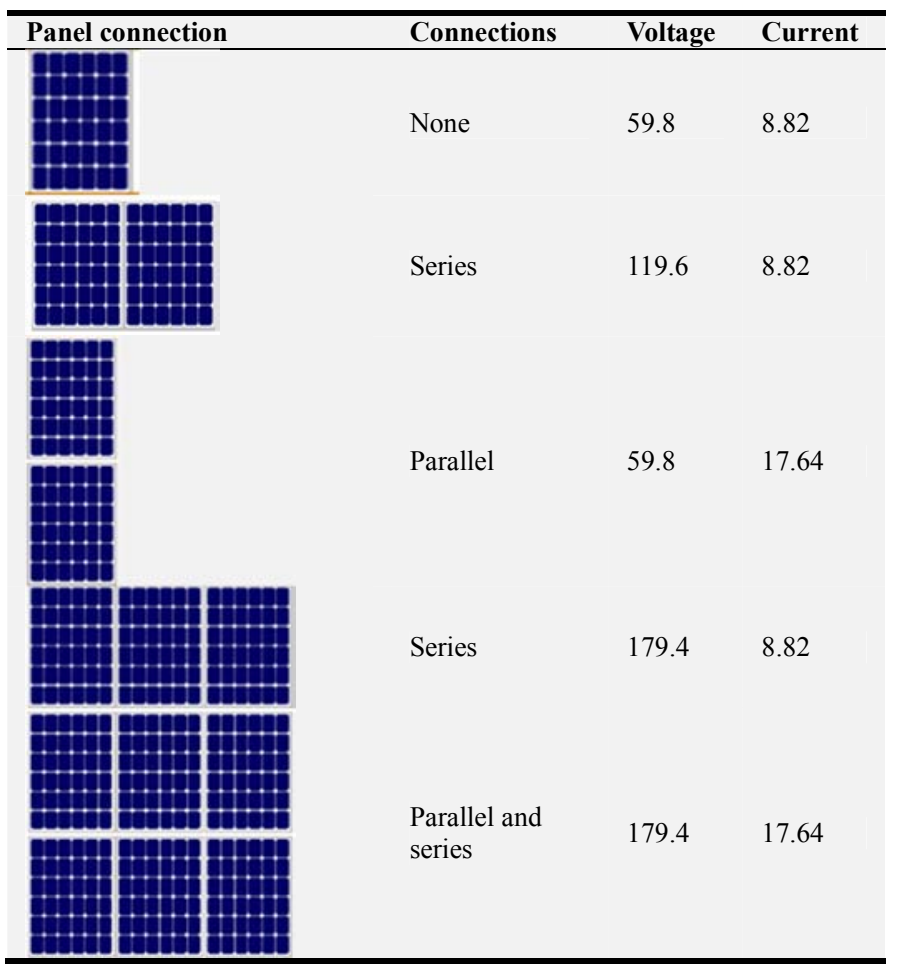

55 panels are required to meet the pump's power requirement. They were wired in series to provide the necessary voltage for the pump power needed.

\section{ii. Electrical Connection of Modules}

Solar panels have a negative (-) and a positive terminal $(+)$ similar to the terminals on a battery. PV panels are wired in series by connecting the negative terminal of one panel to the positive terminal of the next panel as shown in Figure 3. When panels are wired in series, the panel voltages are added. If the panel has the characteristics shown in Table 3, the resultant voltage output for panels shown in Table 4 is: $59.8+59.8=119.6 v$. The current output would be the same as for an individual panel or $8.82 \mathrm{~A}$.

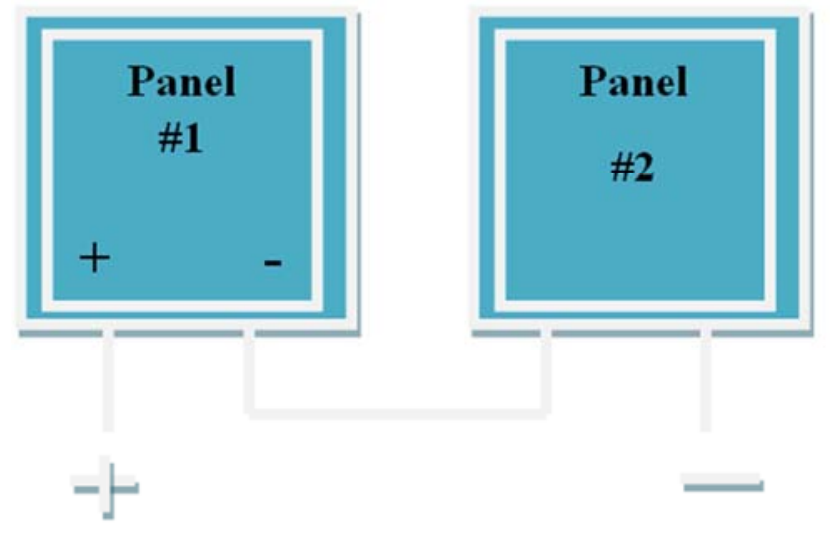

Figure 4. Solar panels wiring in series.

Now we need to input power that can able to start to move pump power which is to satisfy water demand at command area. We can obtain input power from solar PV module watt peak that obtained by inputting daily, monthly and yearly horizontal solar radiation But it can be fluctuated due to weather changing from period to period once time increase or decrease such as morning, noon and evening whether the power produced might be maximum or minimum it is based on those time these power requirement should be satisfy or greater than water power delivered by the pump.

\subsection{System Simulation}

\subsubsection{Simulation Using by PVsyst Software}

From the below figure can be observe irradiance of site and describe loss factor of energy on solar array and by using this irradiance can be calculate peak sun hours.

PVsyst software is able to import meteo data from many different sources as well as personnel data. The software consists of three main design steps. The preliminary design option allows evaluating grid-connected, stand-alone and pumping systems, and using monthly values to perform a quick evaluation of system yield. For each project the location and the system to be used has to be specified. The program includes predefined values of locations of different parts of the world. The second one is project design option allows to create full-featured study and analysis of grid connected, stand-alone, pumping, and dc-grid systems with accurately system yields computed using detailed hourly simulation data. Different simulation variants, horizon shadings, detailed losses, and real components can be added to make economic evaluations. Reports can be generated after the completion of the project and information can be exported to the clipboard. The last option includes meteorological data, components, solar toolboxes, and the analysis of actual data.

Source:(http://www.pvsyst.com)

Input Parameter for Software

Table 5. Solar PV water pumping system parameter.

\begin{tabular}{ll}
\hline Parameter & Values \\
\hline Water required for command area & $6.721 / \mathrm{s}$ \\
Water yield from the well & $91 / \mathrm{s}$ \\
Total head & $162.5 \mathrm{~m}$ \\
Pump power & $20 \mathrm{kw}$ \\
Pump motor efficiency & 0.70 \\
Pumping rate (peak sun hour) & $6.27 \mathrm{hour} /$ day \\
Duty & $1.681 / \mathrm{s} / \mathrm{ha}$ \\
Irrigated land by hectare & $4 \mathrm{ha}$ \\
Piping length & $1000 \mathrm{~m}$ \\
Pipes types & PVC \\
\hline
\end{tabular}

Table 6. Pump characteristics.

\begin{tabular}{ll}
\hline Manufacturer & Hebei, china \\
\hline Model & YQS200-22 \\
Pump Technology & Centrifugal multistage \\
Power & $20 \mathrm{kw}$ \\
Motor & Asynchronous motor \\
\hline
\end{tabular}

Stand Alone System: Detailed User's needs 


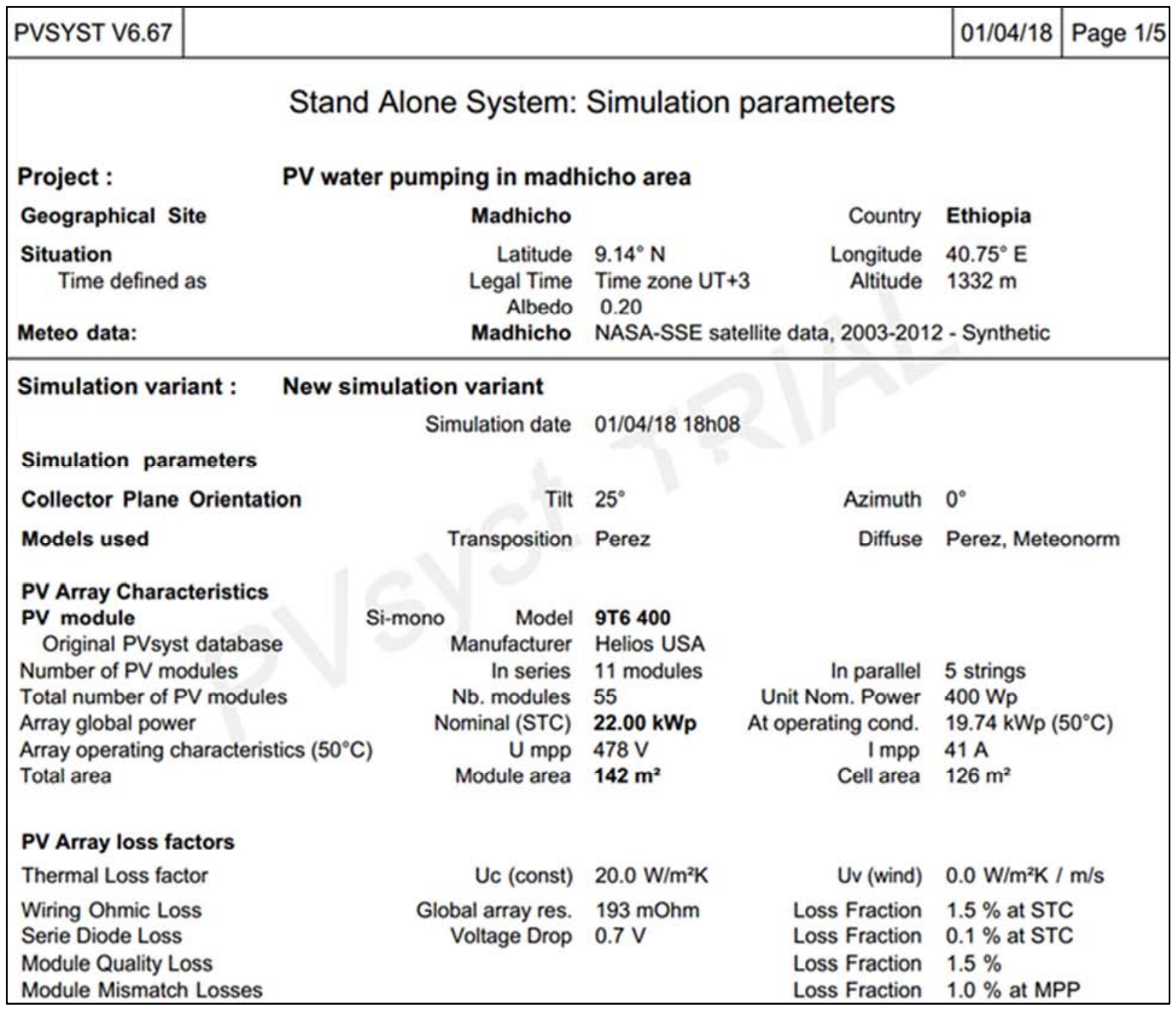

Figure 5. Simulation parameter.

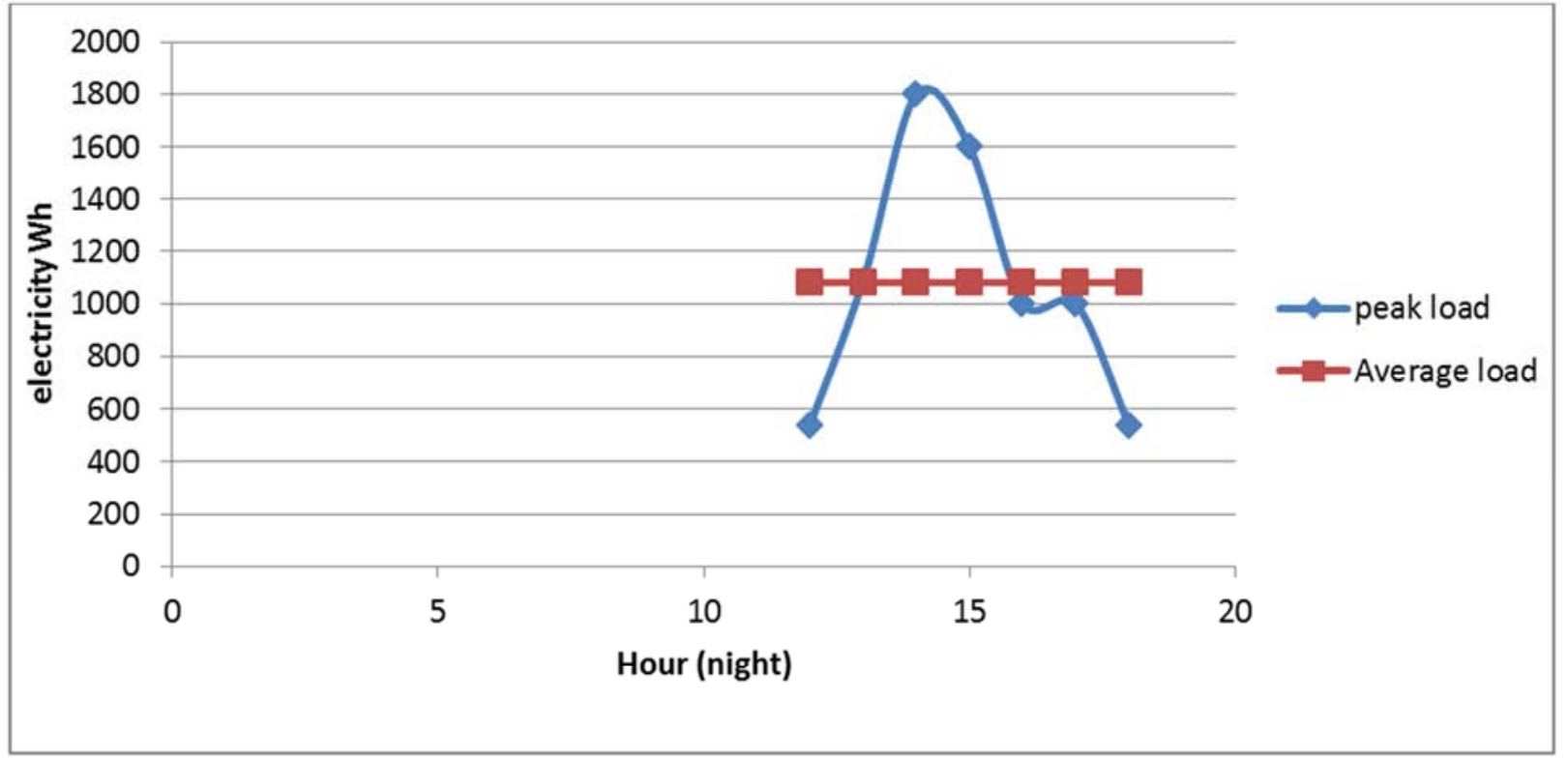

Figure 6. Load curve for community-Lamp. 
Table 7. Output energy required of Winter season.

\begin{tabular}{lllll}
\hline & Number & power & use & Energy \\
\hline $\begin{array}{l}\text { irrigation } \\
\text { Total daily energy }\end{array}$ & 1 & $3667 \mathrm{w}$ tot & $6 \mathrm{~h} /$ day & $22002 \mathrm{wh} /$ day \\
& & & $22002 \mathrm{wh} /$ day \\
\hline
\end{tabular}

Table 8. Daily energy consumptions in Summer season.

\begin{tabular}{llllll}
\hline \multicolumn{2}{l}{ Daily consumption } & & & & \\
\hline Number & Appliance & Power & Dialy use & Hourly distrib & Daily energy \\
\hline 100 & Lamps(LED or fluo) & $18 \mathrm{w} / \mathrm{lamp}$ & $4.0 \mathrm{~h} /$ day & ok & $7200 \mathrm{wh}$ \\
98 & TV/pc/mobile & $75 \mathrm{w} / \mathrm{app}$. & $3.0 \mathrm{~h} /$ day & ok & $22050 \mathrm{wh}$ \\
89 & Domestic appliance & $200 \mathrm{w} / \mathrm{app}$ & $1.0 \mathrm{~h} /$ day & ok & $17800 \mathrm{wh}$ \\
85 & Fridge/deep-freeze & $1.00 \mathrm{kwh} /$ day & $24.0 \mathrm{~h} /$ day & ok & $85068 \mathrm{wh}$ \\
\hline
\end{tabular}

load curve for community

the figure 6 shows that the people live in rulal area required light only night time from 12:00-5:00hour most of people swith on Lamp from 1:00h upto 4:00h however after 5:00h more of switch of the Lamp.

Table 9. Electric load of the community.

\begin{tabular}{lll}
\hline Lamp & & \\
\hline hour & peak load(W) & average load \\
\hline 12 & 540 & $1081 \mathrm{~W}$ \\
13 & 1089 & $1081 \mathrm{~W}$ \\
14 & 1800 & $1081 \mathrm{~W}$ \\
\hline
\end{tabular}

\begin{tabular}{lll}
\hline Lamp & & \\
\hline hour & peak load(W) & average load \\
\hline 15 & 1000 & $1081 \mathrm{~W}$ \\
16 & 1600 & $1081 \mathrm{~W}$ \\
17 & 1000 & $1081 \mathrm{~W}$ \\
18 & 540 & $1081 \mathrm{~W}$ \\
& 7569 & \\
\hline
\end{tabular}

Average load $=$ total peak load/No of hour $=7569 / 7=1081 \mathrm{~W}$ at 12 hour

100 No of Lump 30 lamp becom opened.

$30 * 18 \mathrm{w}=540 \mathrm{w} * 1 \mathrm{~h}=540 \mathrm{wh}$

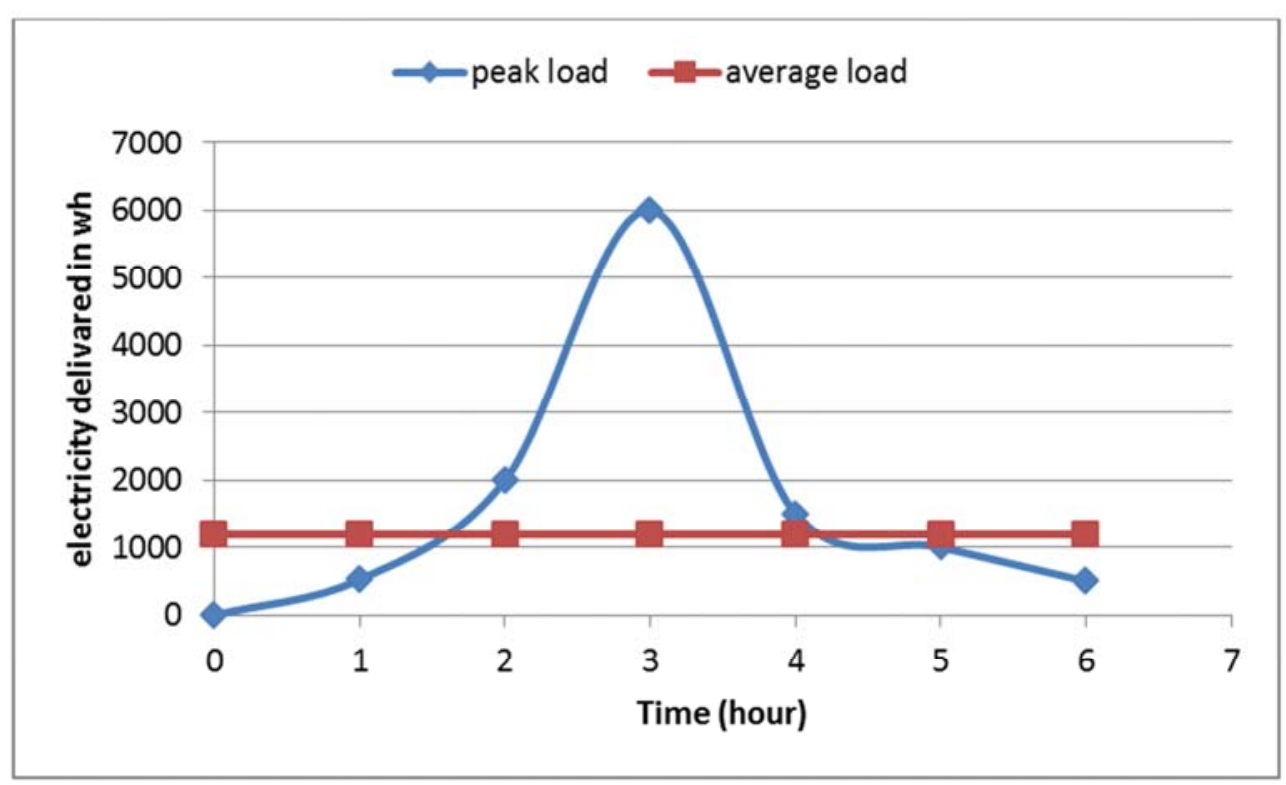

Figure 7. Load curve for community-TV.

Figure 7 indicate that the load curve for rural community TV user the most of people live rural area used TV at night time rather than day time they can be start to open TV 12:00 up to $6: 00 \mathrm{~h}$ but most of user at the same time use from 2:00h$4: 00 \mathrm{~h}$ then decreased.

Table 10. electric load for TV user community.

\begin{tabular}{lll}
\hline Time & peak load & average load \\
\hline 7 & 750 & 2,813 \\
8 & 6000 & 2,813 \\
9 & 1,500 & 2,813 \\
\hline
\end{tabular}

\begin{tabular}{lll}
\hline Time & peak load & average load \\
\hline 10 & 3,000 & 2,813 \\
& Av. load $=2813$ & \\
\hline
\end{tabular}

Battery power supply system(control system) used by control unit Controller Model Universal controller with MPPT converter.

Technology MPPT converter Temp coeff. $\quad-5.0$ $\mathrm{mV} /{ }^{\circ} \mathrm{C} / \mathrm{elem}$.

Converter Maxi and EURO efficiencies 97.0/95.0\% the result in the tab obtained from PVsyst software. 
Table 11. Output energy required and Water demand.

\begin{tabular}{|c|c|c|c|c|c|c|c|c|}
\hline & GlobEff kwh/m2 & Eammpp kwh & E Pmpop kwh & Etkfull kwh & H pump meterW & wpumped $\mathbf{m} 3$ & w used $\mathbf{m} 3$ & W miss $\mathbf{m} 3$ \\
\hline January & 202.4 & 5822 & 3916 & 1587 & 162.7 & 4741 & 4495 & 0 \\
\hline February & 176.9 & 5066 & 3379 & 1423 & 162.6 & 4067 & 4060 & 0 \\
\hline March & 181.3 & 5152 & 3735 & 1126 & 162.6 & 4491 & 4495 & 0 \\
\hline April & 154.2 & 4441 & 3564 & 566 & 162.6 & 4332 & 4350 & 0 \\
\hline May & 154.1 & 4443 & 3672 & 449 & 162.5 & 4453 & 4495 & 0 \\
\hline June & 132.9 & 3919 & 3586 & 45 & 162.5 & 4340 & 4350 & 0 \\
\hline July & 136.1 & 4049 & 3673 & 36 & 162.5 & 4457 & 4495 & 0 \\
\hline August & 148.5 & 4379 & 3733 & 301 & 162.5 & 4511 & 4495 & 0 \\
\hline September & 143.6 & 4160 & 3545 & 264 & 162.6 & 4268 & 4350 & 0 \\
\hline October & 185.1 & 5261 & 3788 & 1141 & 162.7 & 4601 & 4495 & 0 \\
\hline November & 197 & 5594 & 3595 & 1571 & 162.7 & 4418 & 4350 & 0 \\
\hline December & 191.2 & 5522 & 3684 & 1537 & 162.7 & 4495 & 4495 & 0 \\
\hline Year & 2003.3 & 57806 & 43871 & 10145 & 162.6 & 53174 & 52925 & 0 \\
\hline Legend & GlobEff & \multirow{2}{*}{\multicolumn{3}{|c|}{$\begin{array}{l}\text { Effective Global, corr. For LAM and shadings } \\
\text { Array virtual energy at mpp }\end{array}$}} & H pump & \multirow{2}{*}{\multicolumn{3}{|c|}{$\begin{array}{l}\text { Average total Head at pump } \\
\text { water pumped }\end{array}$}} \\
\hline Eammpp & & & & & wpumped & & & \\
\hline E pmpop & & \multicolumn{3}{|c|}{ pump operating energy } & W used & \multicolumn{3}{|c|}{ water drawn by the user } \\
\hline Etkfull & & \multicolumn{3}{|c|}{ Unused energy (tank full) } & W miss & \multicolumn{3}{|c|}{ missing water } \\
\hline
\end{tabular}

PV module: Helios USA, 9T6 400

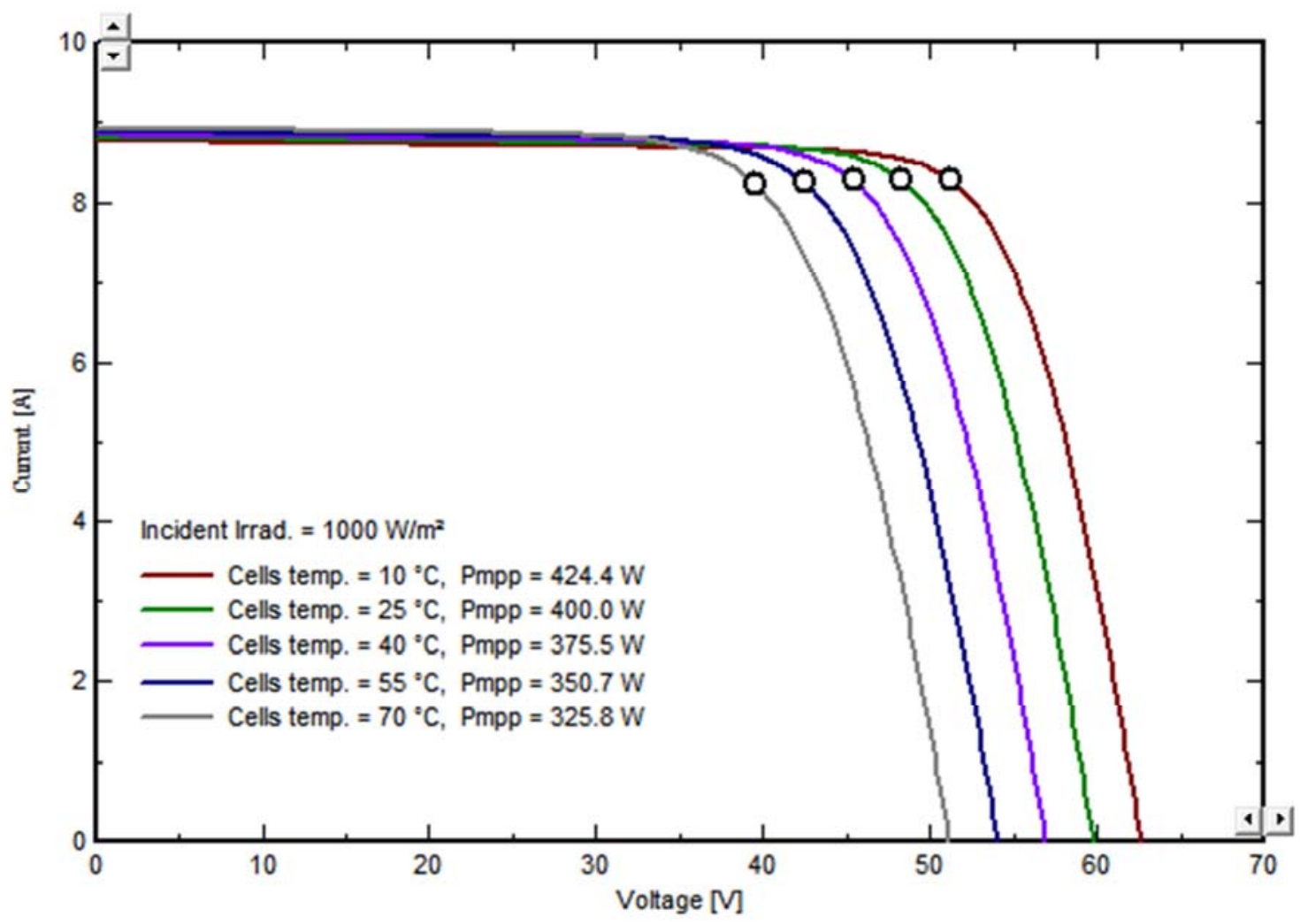

Figure 8. The effect of cells temperature on maximum power point at constant irradiance.

This figure Indicated that at different level available cells temperature increase the PV power produced conversely decrease. The required output power obtained perfectly at $25^{\circ} \mathrm{C}$ cell temperature and also it obtained the result from the process of combining voltage and current.

$$
\mathrm{P}_{\mathrm{mpp}}=45 * 8.89=400.05 \mathrm{~W}
$$

The inputs of PVsyst software for this work are latitude, Altitude, Time zone and longitude of Site, power requirement types of PV panel and etc. As shown in above figure as irradiance of site increase, power produced by PV panel is increase. The power required for solar powered pumping is about $20 \mathrm{~kW}$ can be getting this power at irradiance of $1000 \mathrm{~W} / \mathrm{m}^{2}$. At $1000 \mathrm{~W} / \mathrm{m}^{2}$ irradiance can be produce power. 
PV module: Helios USA, 9T6 400

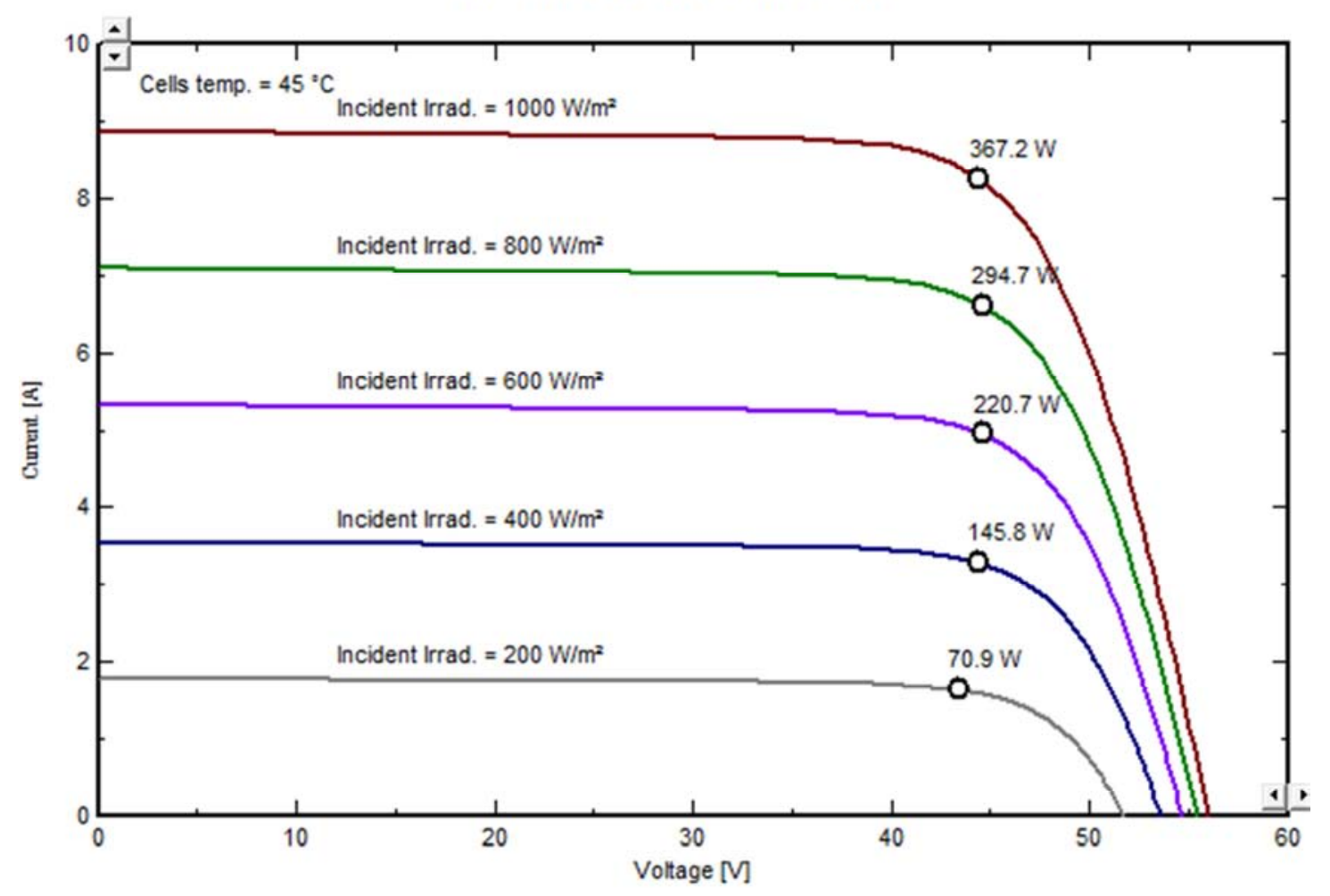

Figure 9. PV power at different irradiance by PVsyst software.

PV module: Helios USA, 9T6 400

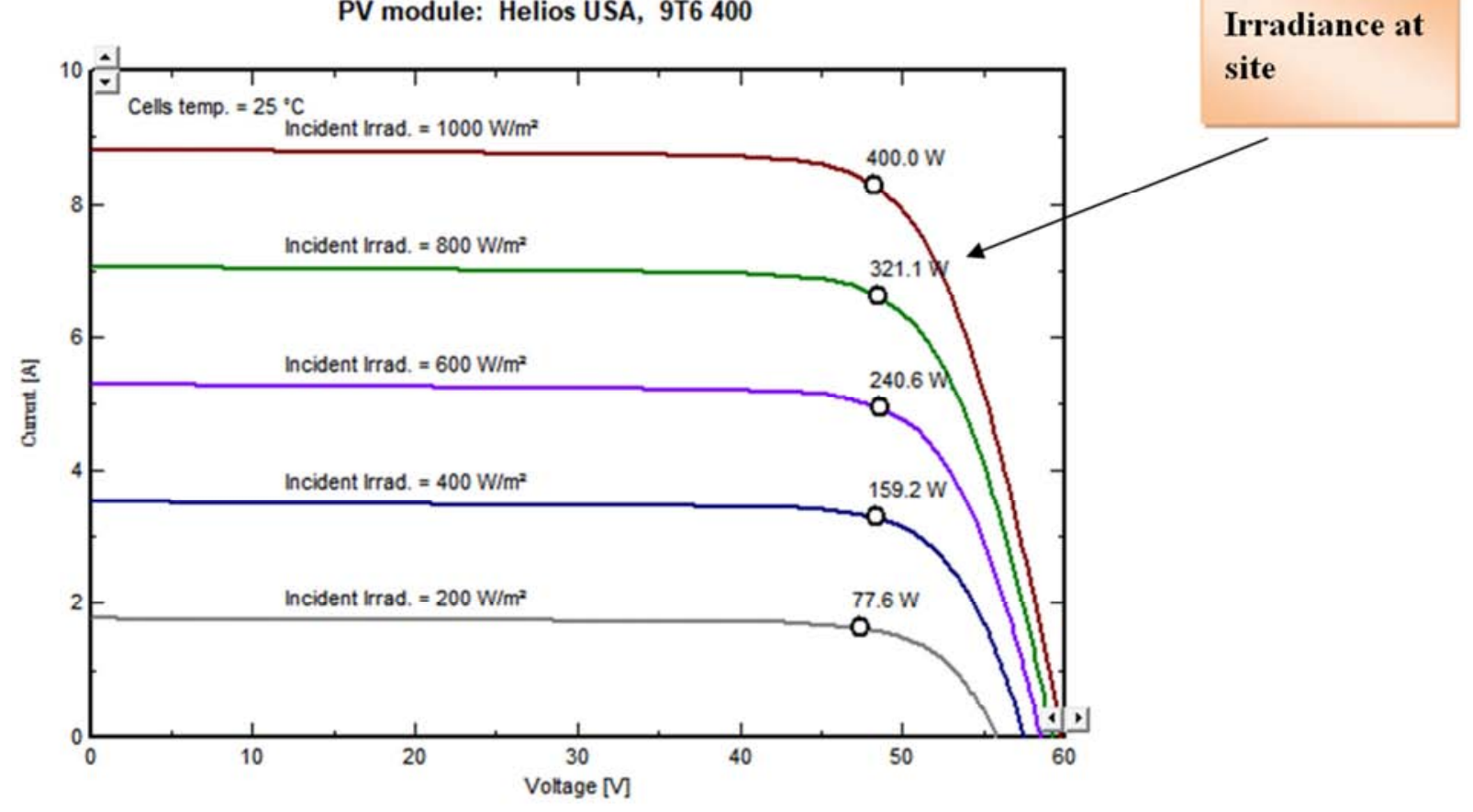

Figure 10. The effect of different irradiance on PV power at constant cell temperature.

$$
\mathrm{P}=\mathrm{V}(\mathrm{V}) * \mathrm{I}(\mathrm{A})=41.23 \mathrm{~V} * 5.9 \mathrm{~A}=367.2 \mathrm{~W}
$$

PV power at different irradiance by PVsyst software at $1000 \mathrm{w} / \mathrm{m}^{2}$ is $367.2 \mathrm{~W}$ while to satisfy power required for solar powered pumping about $20 \mathrm{~kW}$ which is required number of
PV panel about55 which is $367.2 \mathrm{~W}^{*}$ Panel array $22,020 \mathrm{~W}$. But these powers reduce by different

In this case due to maximum cell temperature available on the site the power output is low cause to increase number of PV panel to satisfy power required so that its clear effect on 
the cost of solar module.

What is observed from the graph as the cell temperature increase maximum power point decrease. As cell temperature $25^{\circ} \mathrm{C}$ MPP become $400 \mathrm{~W}$. In my case to satisfy the energy needed we can get selected power based on $25^{\circ} \mathrm{C}$.

For moving solar pumping power $20,000 \mathrm{~W}$ PV solar pane capacity has required can be getting this power at irradiance of $1000 \mathrm{~W} / \mathrm{m}^{2}$. At $1000 \mathrm{~W} / \mathrm{m}^{2}$ irradiance can be produce power.

$$
\mathrm{P}=\mathrm{V}(\mathrm{V}) * \mathrm{I}(\mathrm{A})=45 \mathrm{~V} * 8.9 \mathrm{~A}=400 \mathrm{~W} .
$$

In this case during moderate cell temperature presented in site study the power output is high it cause to decrease number of PV panel to satisfy power required so that it has significant benefit to decreasing the cost of solar module. Therefore to satisfy the power demand in the system the number of photovoltaic panel required in this research is fifty five (55).

PV module: Helios USA, 9T6 400

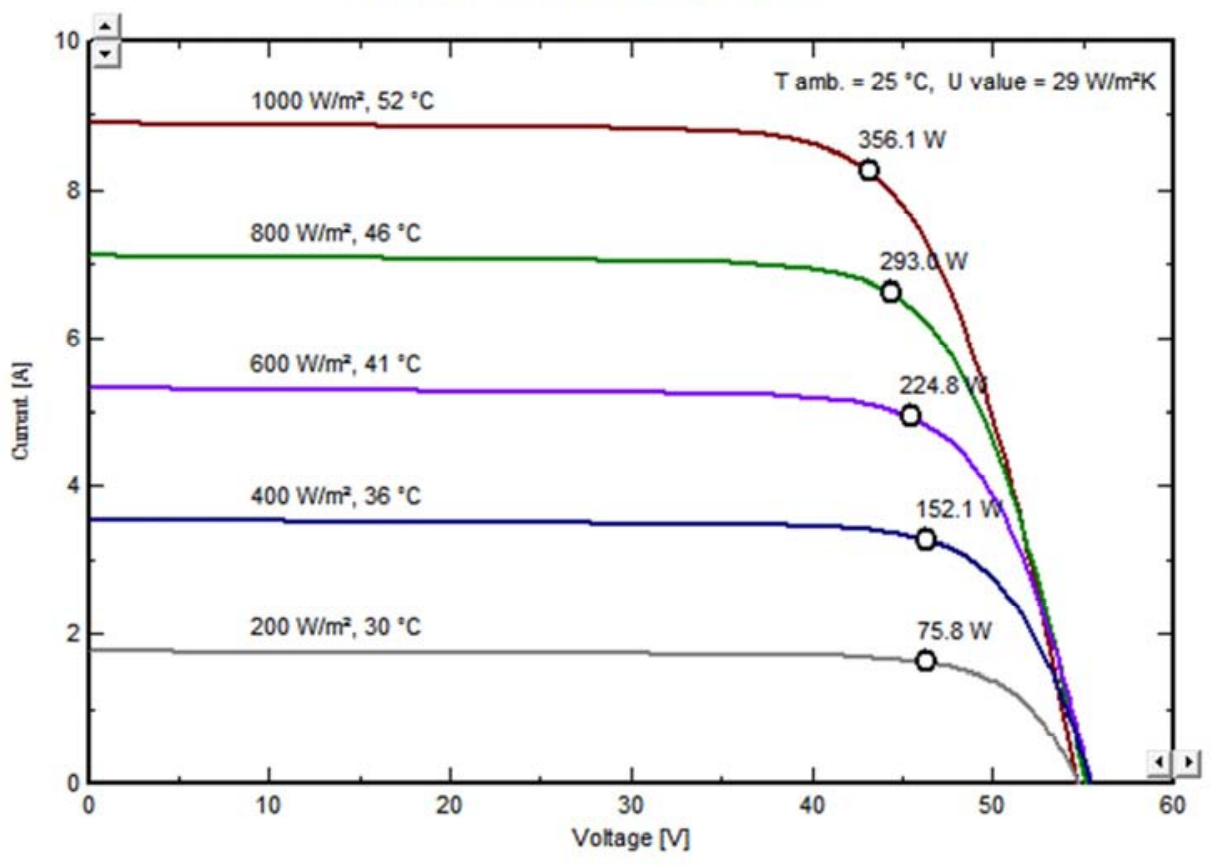

Figure 11. Effect of ambient temperature at different irradiance on PV power output.

PV module: Helios USA, 9T6 400

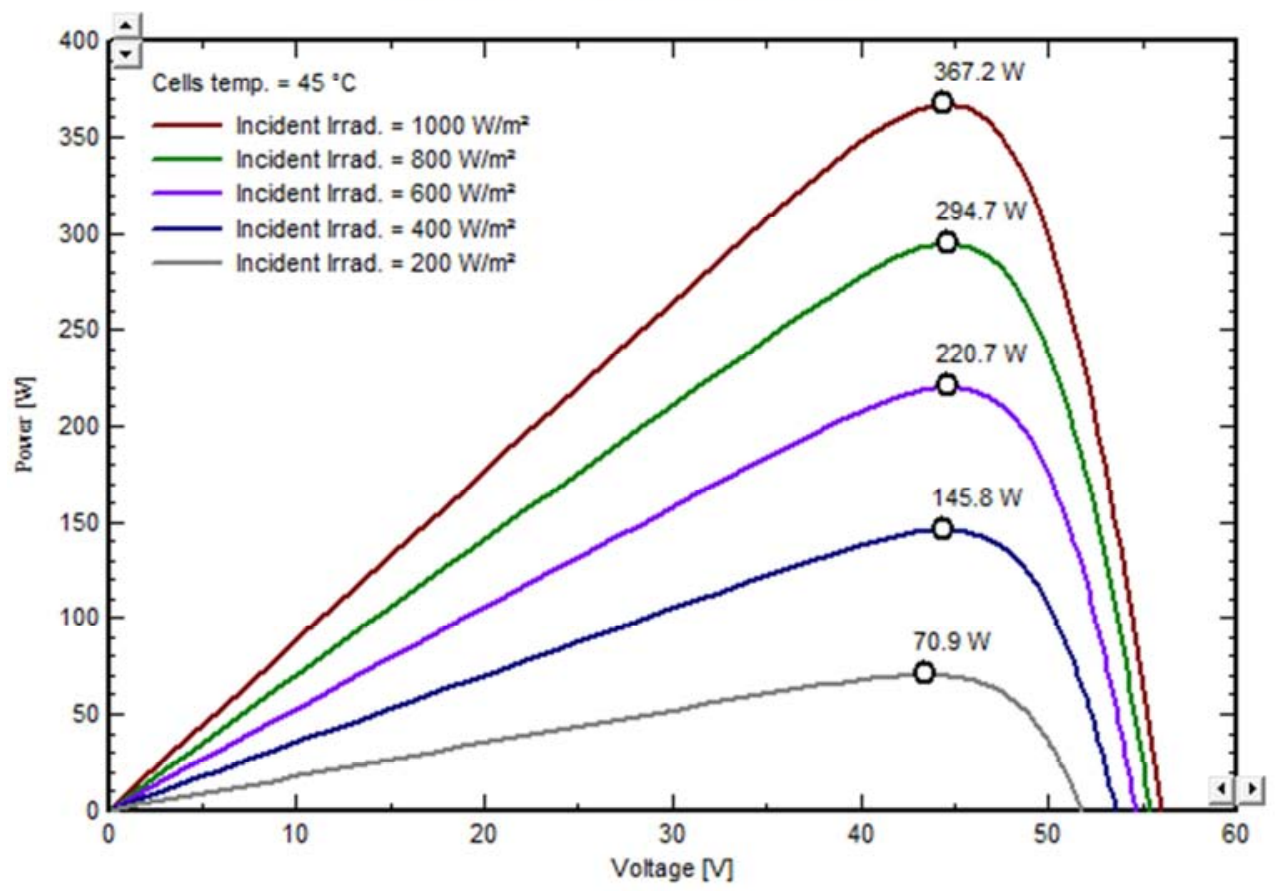

Figure 12. Effect of irradiation on power output. 


\section{Normalized productions (per installed kWp): Nominal power $22.00 \mathrm{kWp}$}

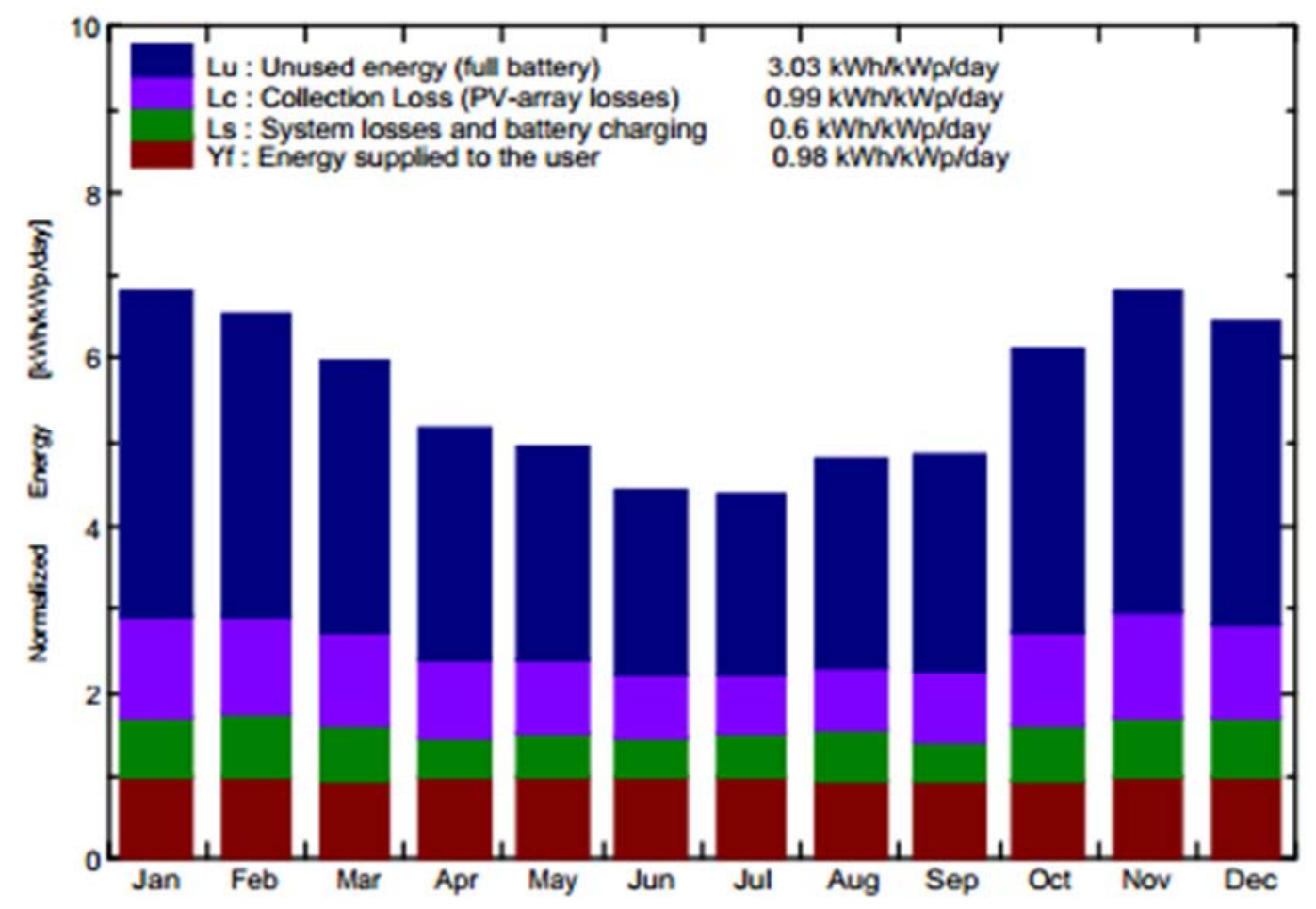

Figure 13. Normalized production.

From the above figure Shows that the effect of ambient temperature at different irradiance has significant effect on maximum power output. Meaning that as ambient temperature increase parallel with increasing irradiance the maximum output power point also increased.

As illustrated in Figure shows that at constant temperature the change in irradiation has a clear effect on the PV output maximum power. It's clearly to understand that as the irradiation level increases the PV power output and voltage increases with it. But at change in cell temperature lead to increase or decrease PV power out and Vis versa. In general, the increase in the irradiation level leads to a theoretical increase in the maximum power voltage when there is no change in the cell temperature.

The above figure 13 show that the energy supplied to user is $0.98 \mathrm{kWh}$ per $\mathrm{kW}_{\mathrm{p}}$ per day nominal power $22 \mathrm{kWp}$ with $\mathrm{PV}$-array loss and system loss and battery charging then net energy produced that delivered to pump is $21.56 \mathrm{kw}$.

\subsubsection{RET Screen Simulation Result}

Table 12. Weather data of NASA from 2003-2012 year at study area.

\begin{tabular}{|c|c|c|c|c|c|c|c|}
\hline Month & $\begin{array}{l}\text { Air } \\
\text { temperature }\end{array}$ & $\begin{array}{l}\text { Relative } \\
\text { humidity }\end{array}$ & precipitation & $\begin{array}{l}\text { Daily solar radiation- } \\
\text { horizontal }\end{array}$ & $\begin{array}{l}\text { Atomospheric } \\
\text { pressure }\end{array}$ & Wind speed & $\begin{array}{l}\text { Earth } \\
\text { temperature }\end{array}$ \\
\hline & ${ }^{\circ} \mathrm{C}$ & $\%$ & $\mathbf{m m}$ & $\mathrm{MJ} / \mathbf{m} 2 / \mathrm{d}$ & kpa & $\mathbf{m} / \mathbf{s}$ & ${ }^{\circ} \mathrm{C}$ \\
\hline January & 17.6 & 0.5 & 18.73 & 20.21 & 85.9 & 1.8 & 24.7 \\
\hline February & 19 & 0.5 & 28.28 & 20.91 & 85.9 & 2 & 27.1 \\
\hline March & 20.4 & 0.5 & 92.33 & 21.26 & 85.8 & 1.9 & 29.4 \\
\hline April & 21.2 & 0.6 & 278.45 & 20.36 & 85.7 & 2.2 & 29.6 \\
\hline May & 22.1 & 0.6 & 157.42 & 21.38 & 85.7 & 2.5 & 30.3 \\
\hline June & 22.4 & 0.6 & 93.05 & 19.71 & 85.7 & 3.1 & 26 \\
\hline July & 20.8 & 0.7 & 216.31 & 19.03 & 85.7 & 3.3 & 22.3 \\
\hline August & 20.6 & 0.7 & 267.11 & 19.61 & 85.7 & 3 & 21.9 \\
\hline Setember & 20.9 & 0.7 & 238.57 & 18.06 & 85.7 & 2.3 & 24.3 \\
\hline October & 18.9 & 0.5 & 79.84 & 20.58 & 85.8 & 2 & 25.9 \\
\hline November & 17.2 & 0.5 & 30.98 & 20.58 & 85.9 & 1.9 & 24.8 \\
\hline December & 16.2 & 0.5 & 29.84 & 18.75 & 86 & 1.9 & 24 \\
\hline Annual & 19.8 & 0.6 & $1,530.91$ & 20.05 & 85.8 & 2.3 & 25.8 \\
\hline Source & user-defined & user-defined & user-defined & user-defined & NASA & user-defined & NASA \\
\hline Measured at & & & & & $\mathrm{m}$ & 10 & 0 \\
\hline
\end{tabular}




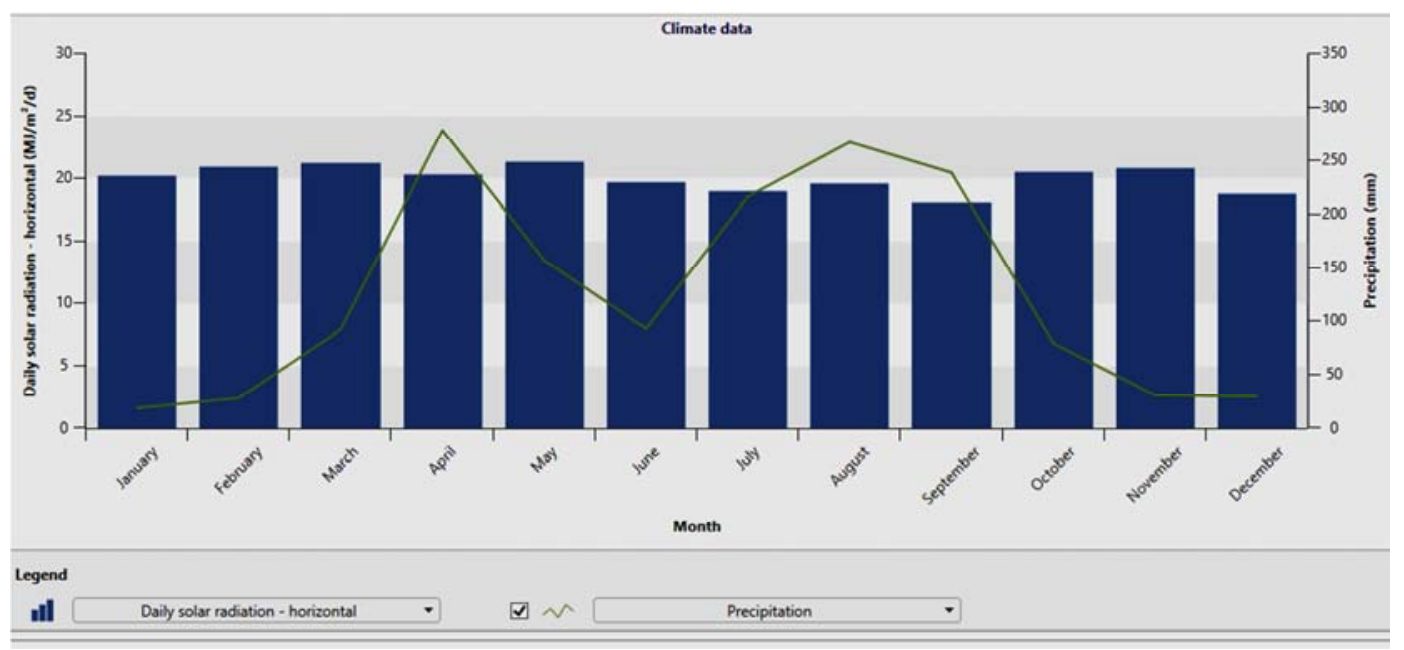

Figure 14. Daily solar radiation horizontal Vs Precipitation.

This graph is show that high solar radiation during month of October to march this time the site can get slightly rare precipitation from June to September the site has enough precipitation during this time no need of irrigation the power goes to appliance.

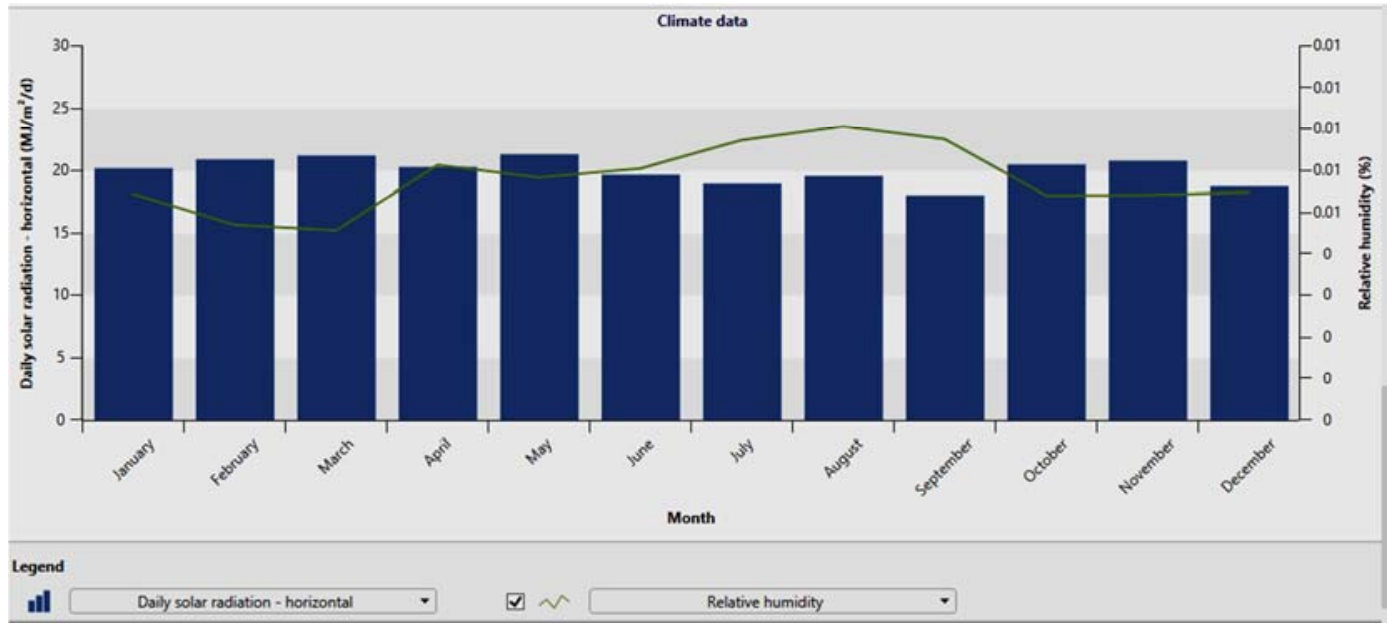

Figure 15. Daily solar radiation horizontal Vs Relative humidity.

The maximum relative humidity indicate slightly low amount of solar radiation at site and decreasing relative humidity result provided increasing irradiance during month of winter season.

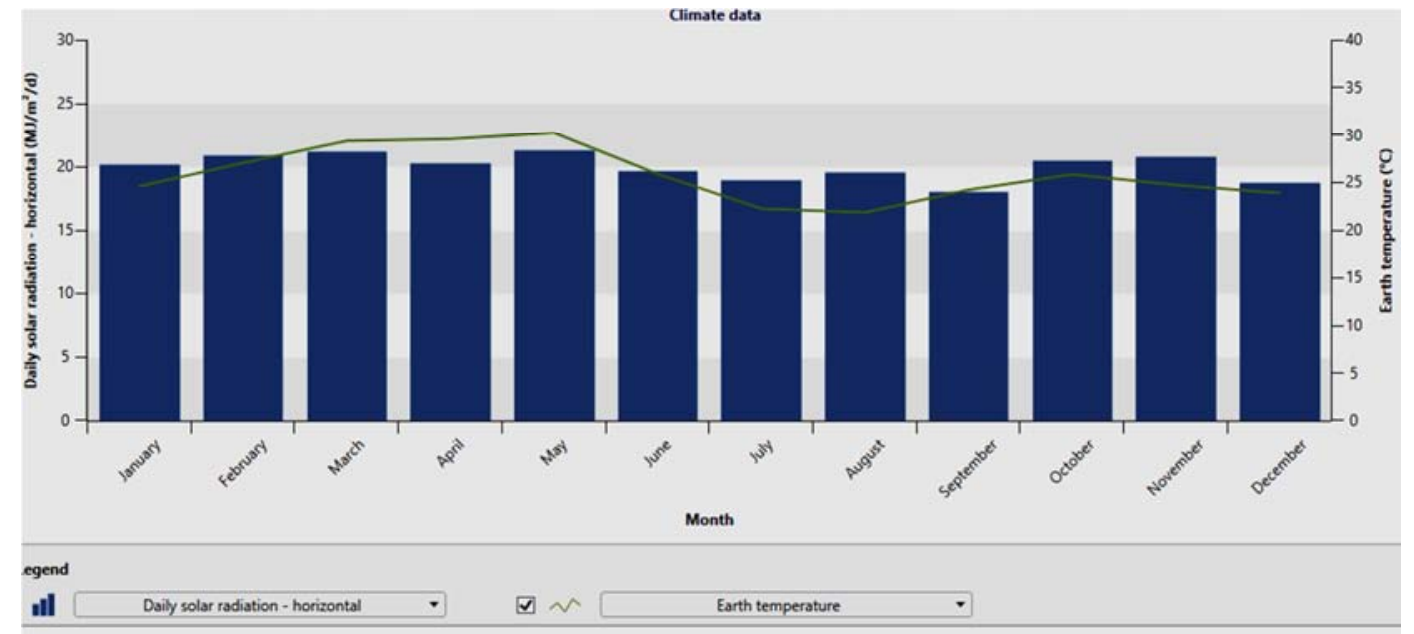

Figure 16. The effect Earth temperature on daily solar radiation horizontal. 
As earth temperature increase the irradiance required at winter season is increased but due to lower the earth temperature in summer season can direct effect on daily solar radiation its result of lower produced power output.

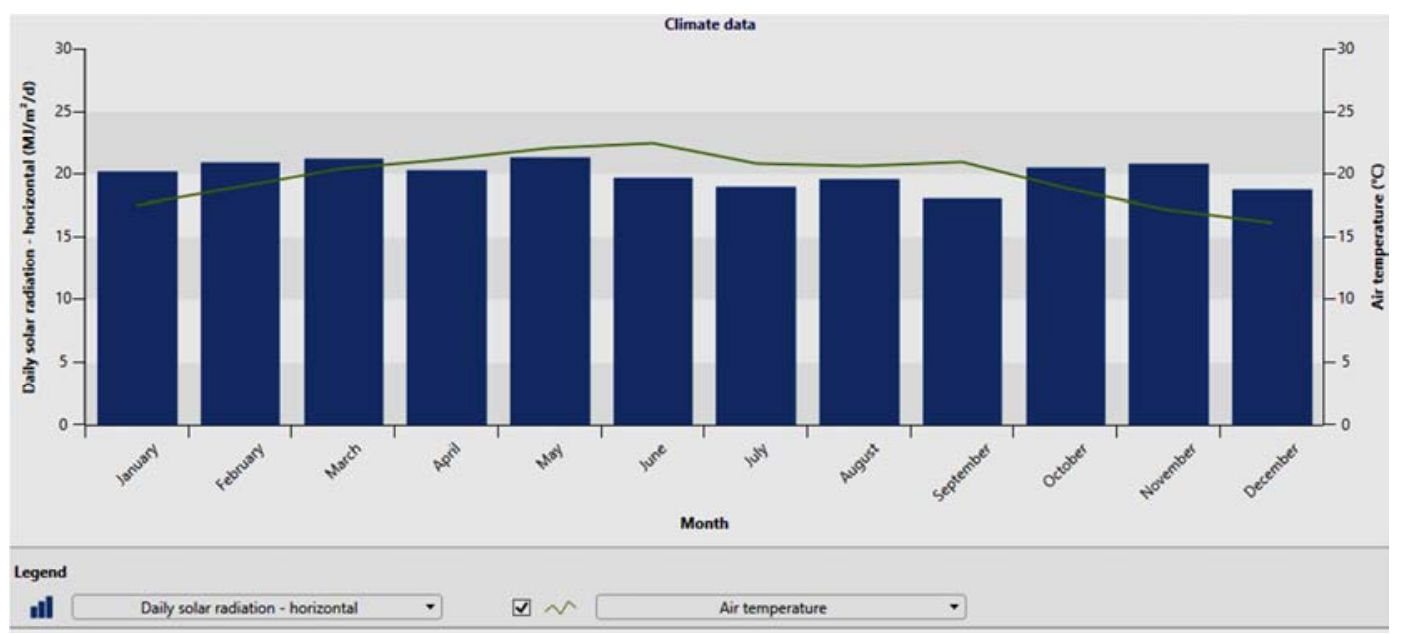

Figure 17. Daily solar radiation horizontal Vs Air temperature.

This graph shows that the air temperature clearly decrease in winter contrary it increase during summer season.

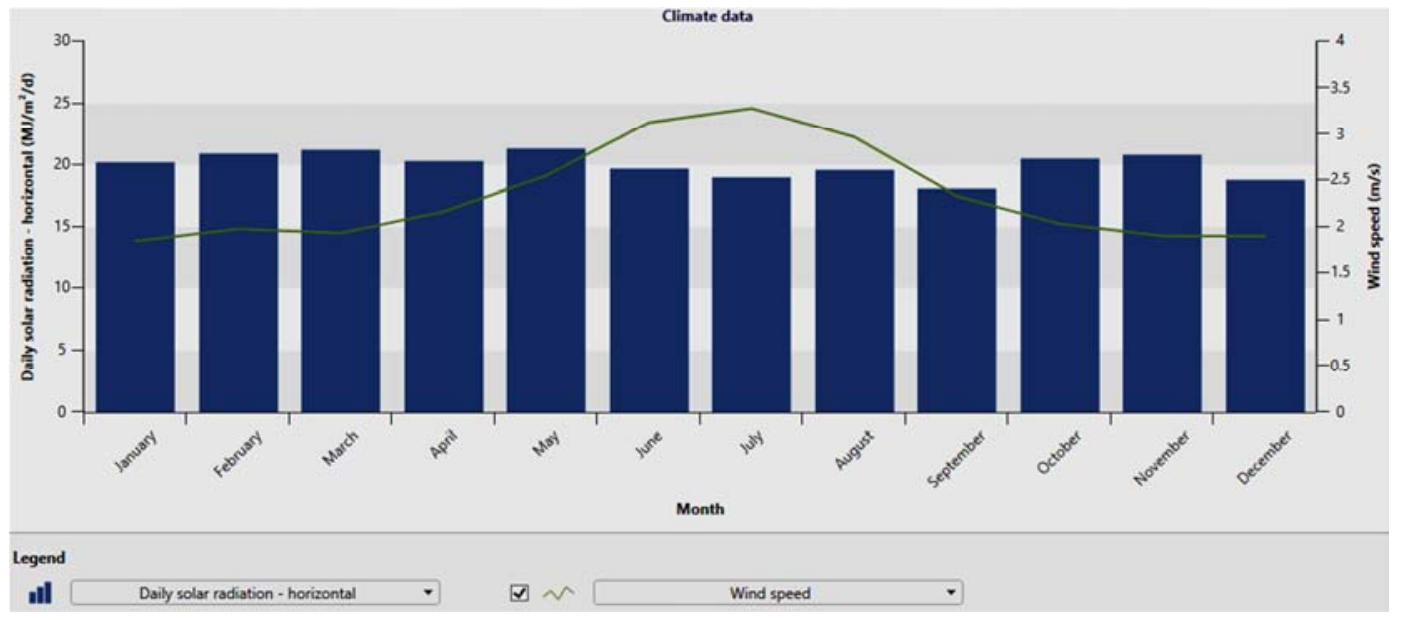

Figure 18. The influence of Wind speed on daily solar radiation.

What was observed from the above graph the highly increased wind speed during summer season lower produced of daily solar radiation its can lead low power output. By inputting peak sun hour and energy required to get output daily electricity required for the proposed system (PV system).

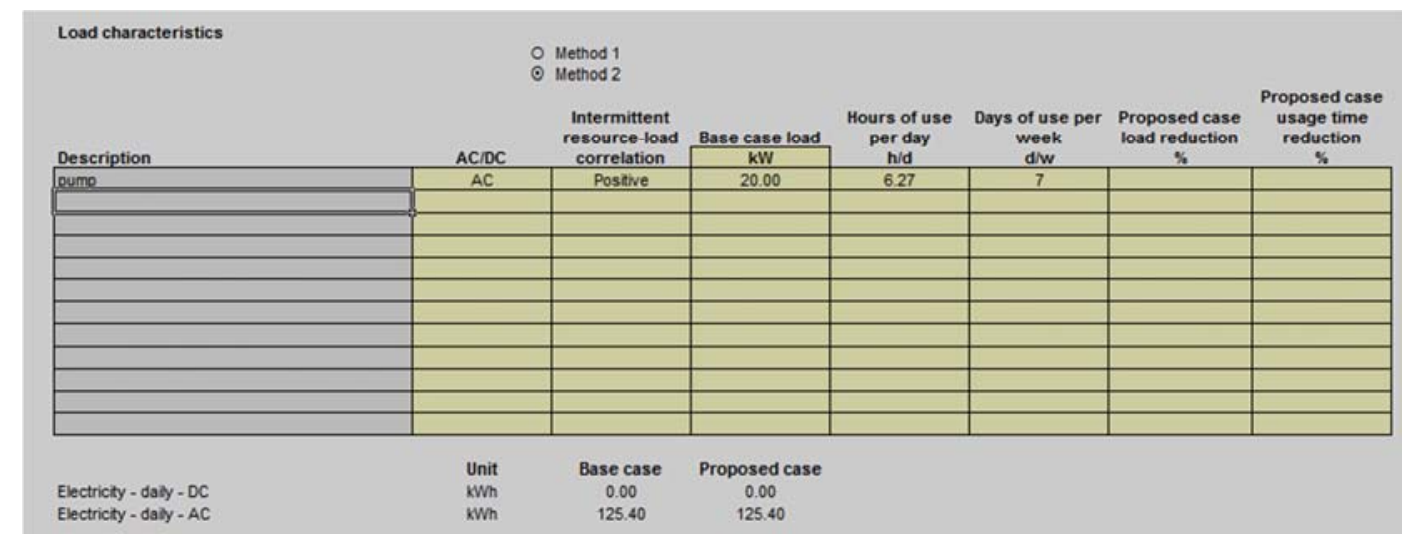

Figure 19. Load characteristics. 


\section{i Energy produced}

The solar PV panel output of DC electricity is delivered to motor pump from solar irradiance data which is taken from figure 19 inputted to RETScreen software can give electricity delivered to pump power.

By inputting average monthly horizontal solar insolation to software that can give output electricity delivered to the system so that it's to more satisfy energy requirement at site.

Table 13. Daily solar radiations on horizontal and tilted surface.

\begin{tabular}{llll}
\hline Month & Daily solar radiation-horizontal $\mathbf{k w h} / \mathbf{m} \mathbf{3} / \mathbf{d}$ & Daily solar radiation-titled $\mathbf{k w h} / \mathbf{m} \mathbf{2} / \mathbf{d}$ & Electricity delivered to load $\mathbf{m w h}$ \\
\hline January & 5.61 & 7.51 & 4.57 \\
February & 5.81 & 7.43 & 4.07 \\
March & 5.91 & 6.77 & 4.14 \\
April & 5.66 & 5.86 & 3.51 \\
May & 5.94 & 5.81 & 3.6 \\
June & 5.48 & 5.25 & 3.18 \\
July & 5.29 & 5.12 & 3.22 \\
August & 5.45 & 5.5 & 3.72 \\
September & 5.02 & 5.43 & 3.26 \\
October & 5.72 & 7.19 & 4.37 \\
November & 5.79 & 7.61 & 4.53 \\
December & 5.21 & 7.18 & 4.38 \\
Annual & 5.57 & 6.38 & 46.54 \\
\hline
\end{tabular}

The above output power obtained from the software is to satisfied the power required for pump at the winter season basically this energy is needed for two season first season for four month (October, November, December and January) second season also for month (February, March, April and May)

Winter energy available

In the winter 240 day /year are available the summation of monthly electricity delivered to the load is: $4.57+4.07+4.14+3.51+3.60+4.37+4.53+4.38=33,170 \mathrm{kWh}$ Tables $4-12$

Total summation of daily energy obtained is $33,170 \mathrm{kWh}$

Energy required for pump in those months $=33,170 \mathrm{kwh} / 240$ day $=138.21 \mathrm{kWh}=22.04 \mathrm{kw} * 0.93$ (system loss) $=20.5 \mathrm{kw}$

This energy produced from system is enough for pump power of $20 \mathrm{~kW}$

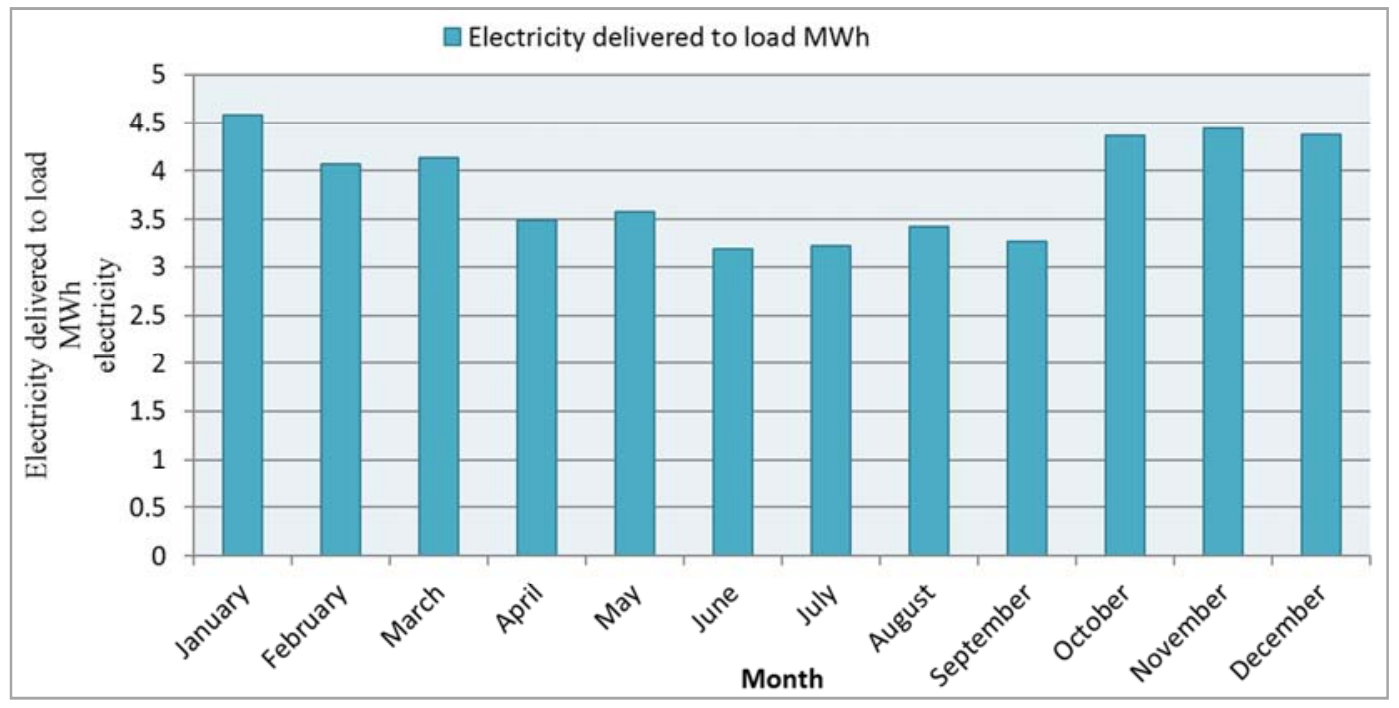

Figure 20. Electricity delivered to load Mwh.

\section{ii No-tracking mode}

Winter: to produce high electricity delivered to the load the slope or inclination angle should be increased within the fixed mode conversely in summer mode the slope will be decreased to generate the maximum electricity delivered to the load the slope also indicate that the daily solar radiation tilted at summer and winter might be varies. In order to optimize electricity delivered to target used which is based on different slope angle that found in two season winter and summer

iii In case at slope of winter

In winter season at study area indicated that high slope angle resulted high electricity outcome

iv In case at slope of summer

Summer mode of fixed solar mode decreasing angle of inclination or slope angle by the solar panel can be resulted 
to increased energy output.

\subsubsection{Working Principle}

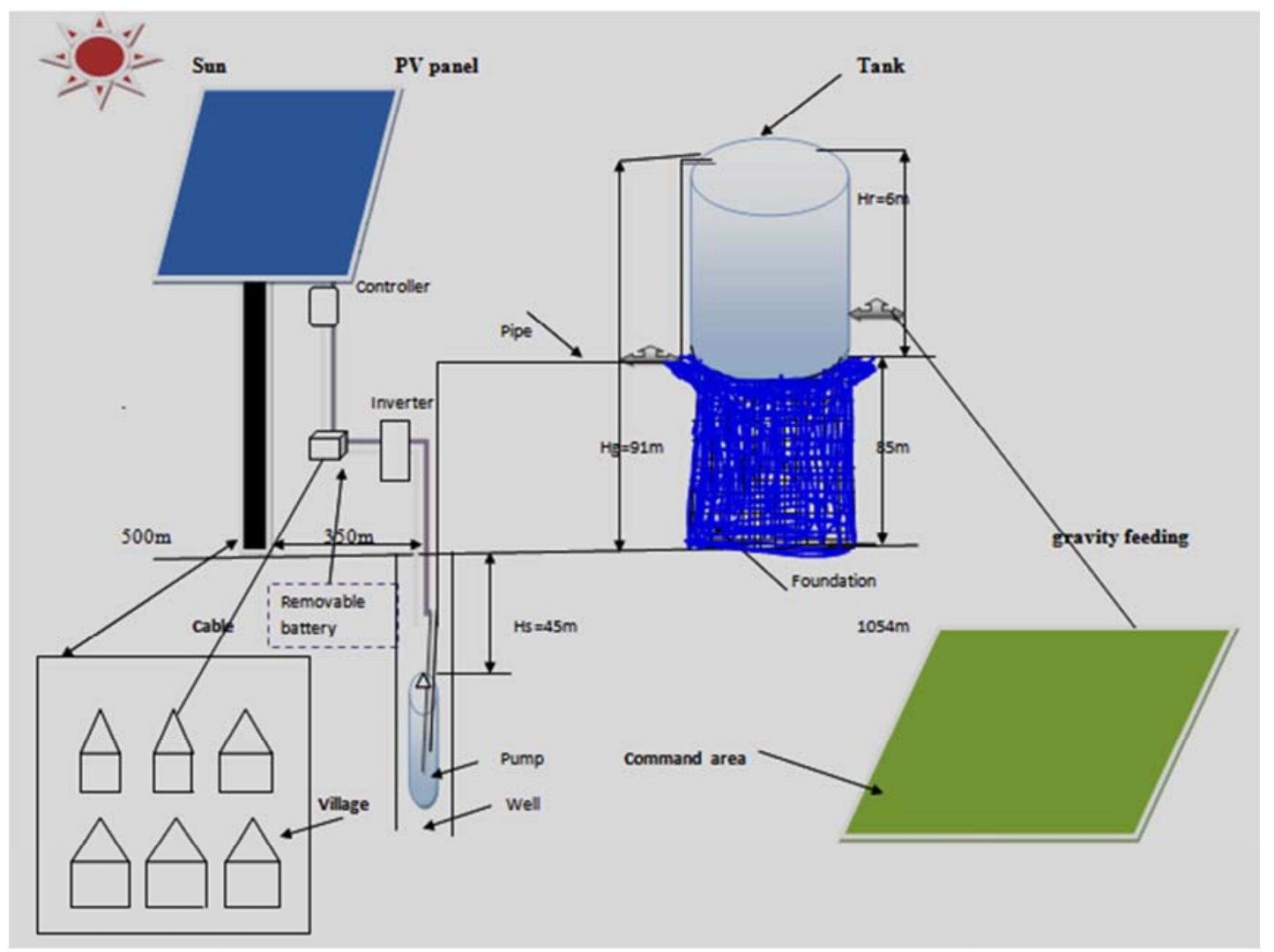

Figure 21. Schematic diagram for solar PV water pumping system.

The system is working directly coupled in order to supply maximum amount of power during peak sun hours of pumping at the time of winter season; however, when no need of irrigation solar removable battery can to the system in summer season consequently, the power attained from PV panel used for other purpose.

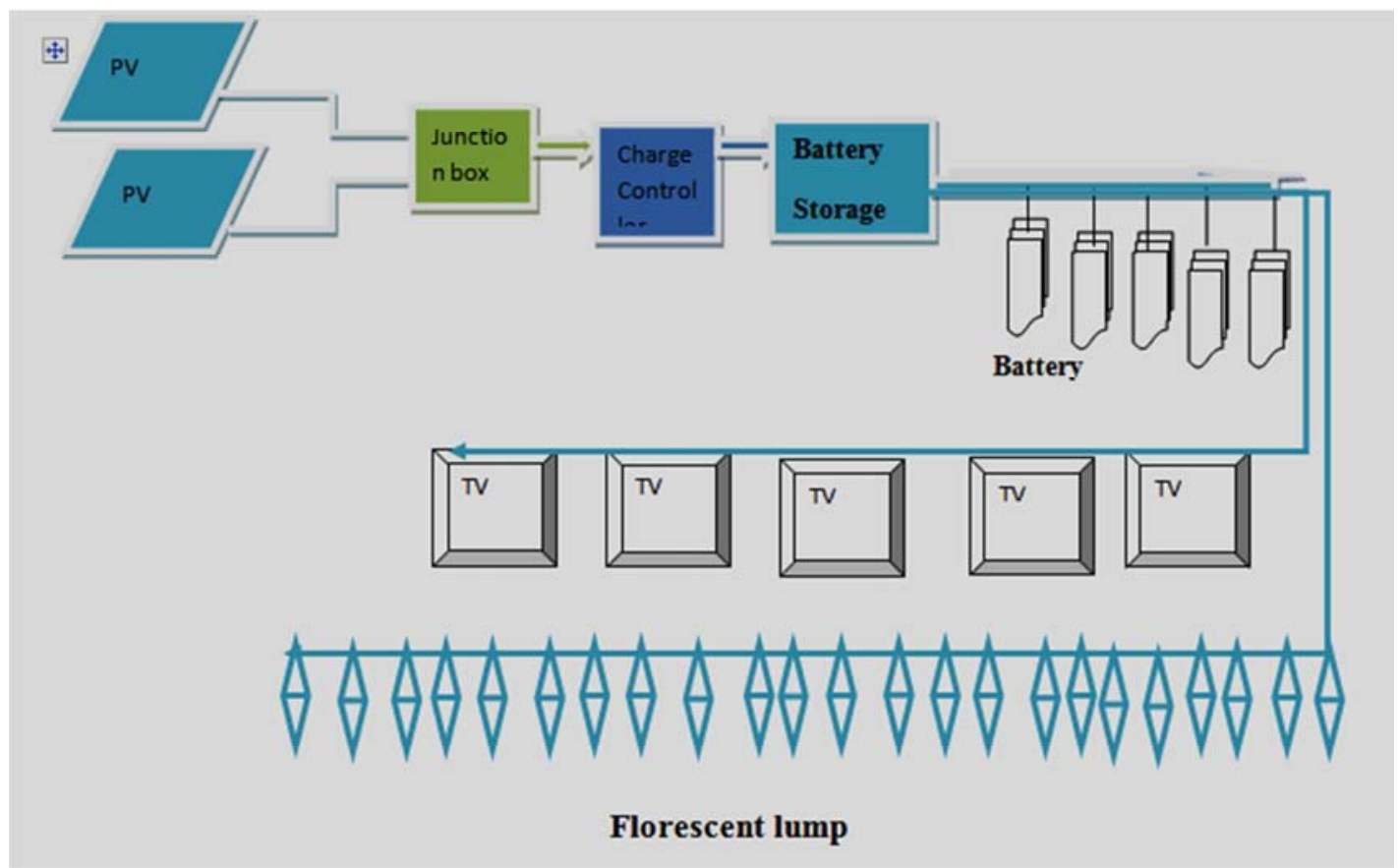

Figure 22. Summer season flow diagram. 


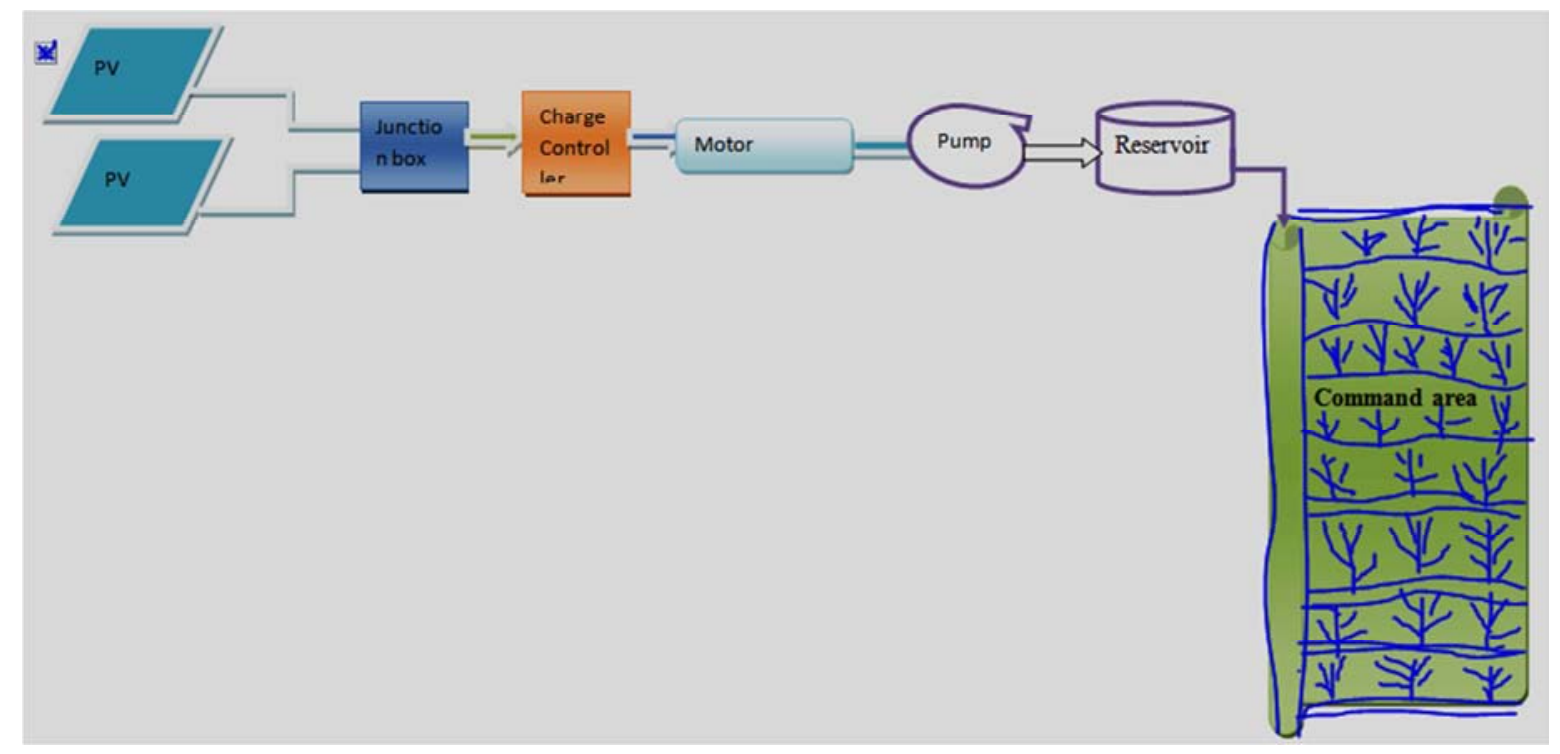

Figure 23. Direct coupled winter season flow diagram.

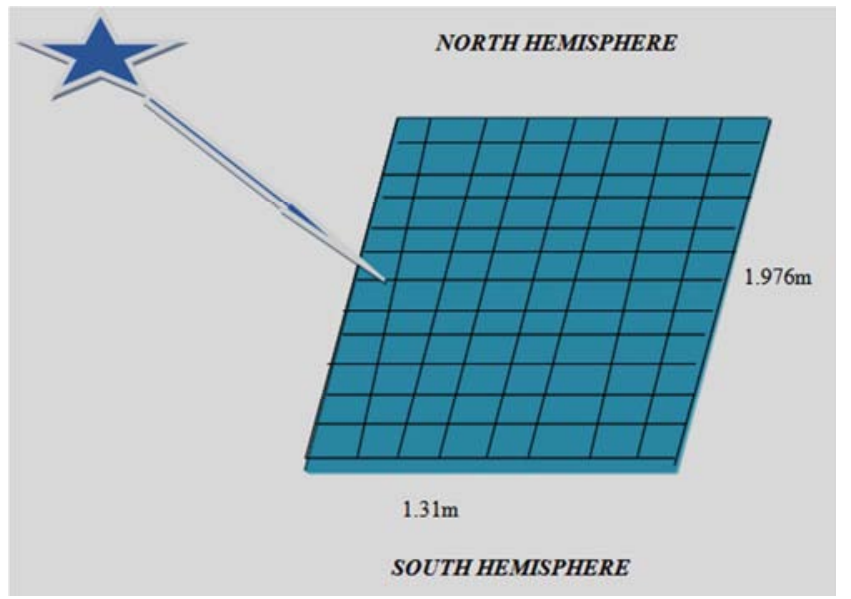

Figure 24. Solar panel.

\section{Conclusions}

Generally Ethiopia has huge potential for solar energy because it is located near the equator with an average daily solar radiation of $5.25 \mathrm{kWh} / \mathrm{m}^{2}$. The Site location of this work is Madhicho kebele at Chiro District and solar radiation data used for design and analysis of solar PV water pumping power for irrigation. A data that collected from different source was compared the average solar radiation calculating. Two Sources of data collected one From NASA and other from recorded data at near site station (MI'ESO). In this study alternatively use solar energy and solve some energy problem in rural area at non-irrigating season using battery for store energy. Analysis of PV water pump by using PVsyst, Ret screen software and also compare solar PV with diesel powered pumping system by making economic to show system feasibility.

The main point that must be focused in this research is to find expected energy required from solar the PV panel which can able to satisfy pump power during winter season and another aspect when the amount of power output is low PV panel power used for multipurpose (Appliance) period of summer season. The required power of the solar panel depends on the amount of energy demand to operate pumping. The Power requirement to operate Pump has power capacity around $27.5 \mathrm{kWp}$ and power requirement for other purpose $132262 \mathrm{Wh}$ per day. It is used as supplementary power for other purpose has to be considered. The minimum solar radiation of site is $5.21 \mathrm{kwh} / \mathrm{m}^{2}$. For the selection of source \& designing of the delivery of water supply project, it is necessary to determine the total quantity of water required for various purposes by the beneficiaries. Actually, the determination of the quantity of water depends up on the size of the command irrigable area and the purpose for which it is needed. On the study area three wells were available to operated with a diesel generator having capacity about 30 $\mathrm{kW}$. The investigation carryout on one wells with submersible AC pumps having $20 \mathrm{~kW}$ power capacity which can able to discharge of $0.009 \mathrm{~m}^{3} / \mathrm{s}$, with total dynamic head of $162.3 \mathrm{~m}$ to meet water required at command area.

\section{References}

[1] Getachew B, Palm B Feasibility study for a standalone solarwind-based hybrid energy system for application in Ethiopia. ApplEnerg 87: 487-495. 2010.

[2] Kelley L. C., Gilbertson E., Sheikh A., Eppinger S. D. and Dubowsky S., On the feasibility of solar-powered irrigation. Renewable and Sustainable Energy Reviews, Vol. 14, pp. 2669-2682, 2010.

[3] Glasnovic, Z, Margeta, J. A model for optimal sizing of photovoltaic irrigation water pumping systems. Solar Energy, 81, 2007.

[4] Abdulbasit Nasir. Design and Simulation of Photo-voltaic Water Pumping System for Irrigation. Advances in Applied Sciences. Vol. 4, No. 2, 2019, pp. 51-63. doi: $10.11648 /$ j.aas. 20190402.14 
[5] Lemu Kebede 2017, Sustainability and Optimal Design of Small-scale Photovoltaic Systems for Rural Applications in Ethiopia. The Center of Energy Technology. Addis Ababa University. Addis Ababa, Ethiopia.

[6] Eker, B and A. Akdogan, Protection methods of corrosion on solar systems, TMMOB Machinery Engineering Society, Mersin, Turkey, 2005.

[7] Abdallah S., The effect of using sun tracking systems on the voltage-current characteristics and power generation of flat plate photovoltaic, Energy Conversion and Management, Vol. 45, pp. 1671-1979, 2004.

[8] Vick B. D. and Clark R. N., Effect of panel temperature on a solar-PV AC water pumping system. ASES Solar 2004: A Solar Harvest Growing Opportunities. July 11-14. Portland.

[9] Huang B. J. and Sun F. S., Feasibility study of one axis three positions tracking solar PV with low concentration ratio reflector. Energy Conversion and Management, Vol. 48, pp. 1273-1280, 2007.

[10] Hansen A. D., Sorensen P., Hansen L. H. and Binder H. Models for a standalone PV system. Riso-R-1219 (EN)/SECR-12, 2000.
[11] Gergaud O., Robin G., Multon B. and Ahmed H. B., Energymodelling of a lead acid battery within hybrid wind/photovoltaic systems. SATIE- Brittany branch, ENS de Cachen- Ker Lan Campus, 2003. ISBN 90-75815-07-7.

[12] Idorenyin Markson, Simeon Ozuomba, Iniobong Edifon Abasi-Obot. Sizing of Solar Water Pumping System for Irrigation of Oil Palm Plantation in Abia State. Universal Journal of Engineering Science 7 (1): 8-19, 2019. Nigeria.

[13] Achaibou N., Haddadi M. and Malek A, Modelling of lead acid batteries in PV systems, Energy Procedia Vol. 18, pp. 538-544, 2012.

[14] Wolde-Ghiorgis W. Renewable energy for rural development in Ethiopia: the case for new energy policies and institutional reform. Energ Policy 30: 1095-1105, 2002.

[15] Wade Byrd Solar ElectricSystemBasics. http://lacleantech.net/solar_electric_systems. pd, 2007.

[16] Rezae A, Gholamian A. Technical andfinancial analysis of photovoltaic water pumping system for Gorgan. Int J Cybern Inform 2013; 2: 2. 